\title{
Online Seyahat Acenteleri Aracılığıyla Seyahat Satın Almada Turist Memnuniyeti: İstanbul Örneği ${ }^{1}$
}

\begin{abstract}
Buket Buluk ${ }^{a^{*}}$, Mustafa Boz
a,bÇanakkale Onsekiz Mart Üniversitesi, Turizm Fakültesi, Çanakkale.

$\ddot{O} z$

Gelişen teknolojinin bir ürünü olarak günlük hayatın değişmezi halini alan internet daha az maliyetle daha hızlı bir şekilde daha fazla müşteriye ulaşma imkanı sunması sebebiyle ticari hayat içerisinde önemli bir yere sahiptir. Turizm ve seyahat endüstrisinde de aynı önemine sahip olan bu araç online seyahat acenteleri ile günümüzde seyahat endüstrisi açısından göz ardı edilemeyecek bir teknoloji yenilik haline getirmiştir. Bu çalışmada amaç, seyahat satın almada klasik seyahat acentelerine klyasla online seyahat acentelerini tercih eden tüketicilerin memnuniyet faktörlerini belirlemek ve her bir faktörün klasik seyahat acentelerine klyasla ne derece memnuniyet sağladığın ölçmektir. Çalışmada ayrıca, online seyahat acentelerinin web sitelerinin taşıması gereken hizmet kalitesi kriterlerini tespit etmek amaçlanmıştır. Araştırma için Szimensky ve Hise (2000)'in geliştirdiği "E-memnuniyet Ölçeği" ve Barnes ve Vidgen (2002) tarafindan geliştirilen "Web Kalitesi Ölçeği" aracıllğıyla bir anket formu oluşturulmuştur. Oluşturulan anket formu tesadüfi olmayan örnekleme yöntemlerinden kolayda örnekleme yöntemi aracılğ̆ıla 2015 Temmuz-Aralık ayları arasında, İstanbul ilini ziyaret eden 530 yerli ve yabancı turiste yüz yüze görüşme yöntemiyle uygulanmıştır. Çalışma sonucunda, katılımcıların demografik değiskenlerine göre e-memnuniyet düzeylerinin ve web sitesi hizmet kalitesi kriterlerine yönelik bakış açılarının farklılaştı̆̆g görülmü̈ştür. Ayrıca, web kalitesi ile katılımcıların e-memnuniyetleri arasında pozitif yönlü bir ilişkinin bulunduğu belirlenmiştir. Çalş̧manın sonuçları literatüre katkı sağlamakla birlikte, turizm ve seyahat endüstrisi pazarlamacıları açısından da önem taşımaktadır.
\end{abstract}

Anahtar Kelimeler: Online seyahat acenteleri, Turist memnuniyeti, İstanbul.

\section{Tourist Satisfaction in Purchasing Trips through Online Travel Agencies: The Case of Istanbul}

\begin{abstract}
The internet which appeared as a result of information and communication technologies affected travel industry as well as other industries. The internet also brought the competition among travel agents to the online area. Since the consumers started to use the internet for travel and holiday bookings, travel agencies have had to use internet more effectively every day and carried out their marketing activities on online platforms. As a result, the importance of website quality has increased for travel agencies implementing marketing activities online. In this research, a questionnaire was created by means of e-satisfaction scale developed by Szymanski and Hise (2000) and web quality scale developed by Barnes and Vidgen (2002). The questionnaire was administered by using deliberate (decisional) sampling which is one of the non-probability sampling methods to 530 local and foreign tourists who visited Istanbul through face to face
\end{abstract}

\footnotetext{
${ }^{1}$ Bu makale, Çanakkale Onsekiz Mart Üniversitesi Sosyal Bilimler Enstitüsünde hazırlanmış olan aynı başlıklı tezden üretilmiştir. Bu tez çalışması, Çanakkale Onsekiz Mart Üniversitesi Bilimsel Araştırma Projeleri Koordinasyon Birimi (BAP) tarafindan desteklenmiştir (Proje No: SYL-2015-685).
}

*Yazışma adresi. E-mail: bulukbuket@comu.edu.tr 
interview method between July and December of 2015. At the end of the study, it was determined that participants' e-satisfaction levels and their perspectives regarding web quality service criteria have changed according to participants' demographic variables. Moreover, it was identified that there is a positive relationship between participants' e-satisfaction and web quality. The results of the study not only contribute to the literature but also tourism and travel industry marketers.

Keywords: Online travel agencies, Tourist satisfaction, Istanbul.

\section{Gíriş}

Son yirmi yılda hızla gelişen ve yaygınlaşan, günümüzde de gelişimini sürdürmeye devam eden bilgi teknolojileri ve internet, uluslararası alandaki değişim sürecinde işletmelerin faaliyet biçimlerini de etkilemiştir (Ünal ve Demirel, 2011; Karataş ve Babür, 2013). Bilgi teknolojileri uygulamaları ve internet sayesinde bilgisayarlar, dijital donanımlar, akıllı telefonlar, tabletler vb. gibi yeni ürün ve hizmetlerin ortaya çıkışı ile birlikte işletmeler ticari faaliyetlerini elektronik ortamda sürdürmeye başlamışlardır. Bilişim teknolojilerinin, işletmelerin bütün faaliyetlerinde yoğun bir şekilde kullanılmaya başlamasıyla birlikte işletmeler, teknolojiyi etkin bir şekilde kullanabilmek için yeniden yapılanmak durumunda kalmışlardır (Ulrich, 2013; Webster, 2014).

Dünya seyahat endüstrisi de bilgi teknolojileri ve internetin beraberinde getirdiği büyük değişimlerden etkilenmiştir. Bu alanda faaliyet gösteren işletmeler için varlıklarını sürdürebilmelerinin ve rekabet güçlerini koruyabilmelerinin tek yolu çevrelerindeki değişim ve eğilimleri yakından izlemek olmuştur (Davies ve Cahill, 2000; Kaynama ve Black, 2000). Bu sebeple birçok acente, bilgi teknolojileri ve internetin beraberinde getirdiği değişim ve gelişmeleri yakından izleyerek işletme politikalarını ve pazarlama faaliyetlerini o yönde oluşturmaya başlamışlardır. Bilgi teknolojileri ve internetin gelişip yaygınlık kazanmasıyla birlikte internet aracılığı ile yapılan seyahat satışları da büyük bir hızla artış göstermiştir (Kim vd., 2007).

Günümüzde seyahat planlamalarının ve rezervasyonların çoğunlukla internet yoluyla yapıldığının bilincinde olan birçok seyahat acentesi "online seyahat acenteciliği" adı altında online platformlarda yer almaya ve tüketicilere online olarak hizmet vermeye başlamıştır (Gretzel ve Yoo, 2008). Online seyahat acenteleri tüketicilere, günün her saatinde ve her yerden otel, uçak bileti vb. hizmetlerle ilgili rezervasyon yapabilme, seyahat destinasyonları hakkında bilgi sahibi olabilme ve bu destinasyonlardaki konaklama alternatiflerini değerlendirebilme imkanı sunmaktadır (Kim vd., 2007). Bu gelişme, online seyahat acentelerini tercih ederek tatil ve seyahat rezervasyonlarını dijital ortamda gerçekleştirenlerin sayısının gün geçtikçe artmasını ve sektörün büyümesini sağlamaktadır (Chen ve Kao, 2010). Ancak, online seyahat acenteleri arasındaki rekabetin de hızla tırmandığı göz önünde bulundurulduğunda, sektörde öne çıkmak için doğru bir pazarlama planı geliştirmenin ve fark yaratmanın önemi ortaya çıkmaktadır (Rianthong vd., 2016). Bu noktada devreye online seyahat acentelerinin web siteleri girmektedir (Bronner ve de Hoog, 2016). Sitenin görsel olarak çekici ve içerik olarak zengin olması ziyaretçiler üzerinde olumlu bir etki bırakmaktadır (Sanchez-Franco ve Rondan-Cataluna, 2010). Böylece ziyaretçilerin 
online seyahat acentelerinin web sitelerinde daha fazla vakit geçirme ve bu süreçte rezervasyon veya satın alma işlemi yapmak için ikna olma ihtimalleri yükselmektedir (Kaynama ve Black, 2000). Bu nedenle, online seyahat acentelerinin web sitelerinin tüketici istek ve beklentilerine göre sahip olması gereken özelliklerin neler olması gerektiği tespit edilmelidir. Web sitelerinin içerik ve sunumlarının rakip online seyahat acentelerinden farklı ve özgün olmasında fayda bulunmaktadır. Bu durum, online seyahat acenteleri için tercih edilme noktasında kolaylık sağlamakta ve sadık müşteri kitlesi oluşturulmasında etkili olmaktadır (Millan ve Esteban, 2004; Kim vd., 2007).

Araştırma, online ve klasik seyahat acenteleri aracılığıyla en az bir defa seyahat satın alma deneyimine sahip olan ve İstanbul ilini ziyaret eden yerli ve yabancı turistlerle sınırlandırılmıştır. Araştırma ile, seyahat acentesi sahiplerine, yöneticilerine ve turizm pazarlamacılarına, online ve klasik seyahat acentelerinin mevcut durumları hakkında fikir verecek sonuçlara ulaşılmıştır. Ayrıca, konu ile ilgili bilimsel çalışmaların eksikliği sebebiyle literatürde yer alan mevcut boşluğun doldurulmasına katkıda bulunulması amaçlanmıştır.

\section{YÖNTEM}

\subsection{Araştırmanın Modeli}

Çalışma kapsamında yapılan literatür araştırması sonucunda e-memnuniyet ve web kalitesi konularını birlikte inceleyen herhangi bir çalışmaya rastlanılmamıştır. Bu nedenle bu çalışmada, turistlerin demografik değişkenlerine göre e-memnuniyet düzeyleri ve web sitesi hizmet kalitesi kriterleri arasındaki farklılıklar incelenmiştir.

Bu doğrultuda araştırmanın hipotezleri aşağıdaki gibi oluşturulmuştur:

$\mathbf{H}_{1}$ : Katılımcların online seyahat acenteleri ve klasik seyahat acenteleri aracılığıyla seyahat satın alma memnuniyet düzeyleri arasında istatistiksel olarak anlamlı farklılıklar vardır.

$\mathbf{H}_{2}$ : Katılımcıların demografik değişkenleri ile e-memnuniyet düzeyleri arasında istatistiksel olarak anlamlı farklılıklar vardır.

H: Katılımcların demografik değişkenleri ile web sitesi hizmet kalitesi kriterleri arasında istatistiksel olarak anlamlı farklılıklar vardır.

H4: Katılımcıların e-memnuniyet düzeyleri ile web sitesi hizmet kalitesi kriterleri arasında istatistiksel olarak anlamlı bir ilişki vardır.

\subsection{Evren ve Örneklem}

Araştırmanın evrenini, Türkiye' nin gerek transit yolcu gerekse konaklama ve ziyaret bakımından en yüksek ziyaretçi oranına sahip şehirlerinden İstanbul'u ziyaret eden yerli ve yabancı turistler oluşturmaktadır. Bu bağlamda araştırmanın örneklemi, İstanbul ilini ziyaret eden yerli ve yabancı turistler içerisinden uyruk değişkenine göre kolayda örnekleme yöntemi aracılığıyla seçilen turistlerden oluşmaktadır. Çalışmada örneklem yöntemi olarak tesadüfi olmayan örnekleme yöntemlerinden kolayda örnekleme yönteminin seçilmesinin nedeni, bu örnekleme yönteminin hızlı ve ucuz yoldan veri elde etmenin en kestirme örnekleme yöntemi olmasından 
kaynaklanmaktadır (Nakip, 2004: 183). Oldukça yaygın olarak kullanılan bu teknikte esas, ankete cevap veren herkesin örneğe dahil edilmesidir. En kolay bulunan denek en ideal olanıdır (Altunışık vd., 2010: 140). Çünkü kolayda örneklemede görüşmeci, gözüne kestirdiği ya da uygun gördüğü kişiye anketi doldurmasını teklif eder (Nakip, 2004: 204).

$\mathrm{Bu}$ araştırmada, katılımcılara uygulanmak üzere toplamda 700 anket hazırlanmıştır. Hazırlanan bu anketler 2015 Temmuz-Aralık ayları arasında İstanbul ilini ziyaret eden yerli ve yabancı turistlerle yüz yüze görüşülerek gerçekleştirilmiştir. Uygulama sonucunda toplamda 590 anket elde edilmiştir. 590 anketin 60 tanesi eksik veya hatalı doldurma sebebiyle kullanım dişı bırakılmış, toplamda 530 anket istatistiksel analizlerde kullanılmıştır.

\subsection{Veri Toplama Arac1}

Araştırmada veriler, Szimensky ve Hise'ın (2000) geliştirdiği E-memnuniyet ölçeği ve Barnes ve Vidgen (2002) tarafından geliştirilen Web kalitesi ölçeği ile elde edilmiştir.

5'li likert tipi formunda toplamda 36 maddeden oluşan ölçekte e-memnuniyet ölçeği altında yer alan 11 ifade için araştırmaya katılan katılımcılardan her maddenin karşısında bulunan "Çok daha kötü", "Daha kötü", "Aynı”, "Daha iyi”, “Çok daha iyi” seçeneklerinden birini işaretlemeleri istenirken, web kalitesi ölçeği altında yer alan 25 madde için ise araştırmaya katılan katılımcılardan her bir maddenin karşısında bulunan "Kesinlikle Katılıyorum", “Katılıyorum", “Fikrim Yok”, “Katılmıyorum” ve "Kesinlikle Katılmıyorum" seçeneklerinden birini işaretlemeleri istenmiştir. Ölçeğin kapsam geçerliğini test etmek için uzman görüşlerine başvurulmuş, yapı geçerliğini saplamak amacıyla da faktör analizi yapılmıştır. Ölçekte yer alan maddeler Açımlayıcı Faktör Analizi tekniklerinden Temel Bileşenler Analizi ile incelenmiştir. Ölçeğin güvenirlik çalışmaları ise Cronbach Alpha iç tutarlılık katsayısı ve madde toplam korelasyonları ile gerçekleştirilmiştir. E-memnuniyet ölçeğinin çalışma grubuna uygulanması sonucu elde edilen verilerin çalışma grubuna uygunluğu .000 düzeyinde Kaiser-Meyer- Olkin $(\mathrm{KMO})=.864$ Bartlett Testi sonucu $\mathrm{x} 2=4723.970$ olarak bulunmuştur. Web kalitesi ölçeğinin çalışma grubuna uygulanması sonucu elde edilen verilerin çalışma grubuna uygunluğu ise, .000 düzeyinde Kaiser-Meyer- Olkin $(K M O)=$ .878 Bartlett Testi sonucu x2=9010.958 olarak bulunmuştur. "Ürün satın alma uygunluğu" ve "Ürün satın alma güvenilirliği" olarak iki faktör altında toplanan Ememnuniyet ölçeğinin birinci faktörü ölçeğe ilişkin toplam varyansın \%51.003'ünü, ikinci faktör ise \%21.635'ini açıklamaktadır. İki faktörün açıkladığı toplam varyans \%72.638'dir. "Kullanılabilirlik", “Teşvik edicilik", “Hizmet kalitesi”, “Verimlilik" ve "Hizmet etkileşimi" olarak beş faktör altında toplanan Web kalitesi ölçeğinin birinci faktörü ölçeğe ilişkin toplam varyansın \%16.953'ünü, ikinci faktör \%15.083'ünü, üçüncü faktör \%14.848'ini, dördüncü faktör \%14.835'ini ve beşinci faktör \%11.288'ini açıklamaktadır. Beş faktörün açıkladığı toplam varyans \%73.007'dir.

E-memnuniyet ölçeğinin birinci faktörü olan "Ürün satın alma uygunluğu" faktörü sırasıyla "Klasik seyahat acentelerine kıyasla, online seyahat acentelerinin zaman tasarrufu sağlaması", "Klasik seyahat acentelerine kıyasla, online olarak ev-ofis 
bilgisayarları, tablet ve cep telefonlarından seyahat/tatil satın alabilme", "Klasik seyahat acentelerine kıyasla, online seyahat acentelerine 7/24 ulaşabilme esnekliği", "Klasik seyahat acentelerine kıyasla, online seyahat acentelerine doğrudan ve anında bilgi erişimi sağlama", "Klasik seyahat acentelerine kıyasla, online sunulan turizm hizmetlerinin (uçak biletleri, otel, vb.) sayısı", "Klasik seyahat acentelerine kıyasla, online sunulan turizm hizmetlerinin (uçak biletleri, otel, vb.) çeşitliliği", "Klasik seyahat acentelerine kıyasla, online sunulan turizm hizmetlerinin (uçak biletleri, otel, vb.) bilgi miktarı", "Klasik seyahat acentelerine kıyasla, online seyahat acentelerinin uygun fiyat seçenekleri" olarak sekiz maddeden oluşmaktadır. E-memnuniyet ölçeğinin ikinci faktörü olan "Ürün satın alma güvenilirliği” faktörü ise "Klasik seyahat acentelerine kıyasla, online seyahat acentelerinin bilgi kalitesi", "Klasik seyahat acentelerine kıyasla, online işlemlerin güvenilirliği" ve "Klasik seyahat acentelerine kıyasla, online seyahat acentelerinin kişisel mahremiyet ve gizlilik durumu" olarak üç maddeden oluşmaktadır.

Web kalitesi ölçeğinin birinci faktörü olan "Kullanılabilirlik" faktörü sırasıyla "web sitenin dizaynı ve sunuşu çekici olmalıdır", "web sitesi ziyaretçilerine kullanım kolaylığı sağlamalıdır", "web sitesinde ziyaretçilerin aradığı bilgiye hızlıca ulaşmasını sağlayabilmek için site haritası, site içi arama motoru gibi uygulamalar bulunmalıdır", "web sitesi seçenekleri sıralama/sınıflandırma özelliği bulunmalıdır", "web sitesi kesintisiz sayfalar ile sitede gezinme ve satın alma imkanı sunmalıdır" olmak üzere beş maddeden oluşmaktadır. Web kalitesi ölçeğinin ikinci faktörü olan "Teşvik edicilik" faktörü ise sırasıyla "web sitesinde çoklu dil seçeneği yer almalıdır", "web sitesi ziyaretçilerine uygun fiyat seçenekleri sunmalıdır", "web sitesi ziyaretçilerine farklı ödeme seçenekleri sunmalıdır" olmak üzere üç maddeden oluşmaktadır. Web kalitesi ölçeğinin üçüncü faktörü olan "Hizmet kalitesi" faktörü sırasıyla "web sitesinde sunulan hizmetlerle ilgili görsel bilgiler (video, fotoğraf) yer almalıdır", "web sitenin hızı yüksek olmalıdır", "web sitenin canlı destek hattı bulunmalı ve aktif olarak çalışmalıdır", "web sitenin bir iletişim sayfası ve çağrı merkezi bulunmalıdır" olmak üzere dört maddeden oluşmaktadır. Web kalitesi ölçeğinin dördüncü faktörü olan "Verimlilik" faktörü sırasıyla "web sitesi ziyaretçilerine esnek rezervasyon imkanı sunmalıdır", "web sitesinde tek bir işlemle tüm seyahat hizmetleri rezervasyon yapılabilmelidir", "web sitesinde kolay değişiklik yapma, iptal ve istek özelliği bulunmalıdır", "web sitesi ziyaretçilerine acenteyi ve faaliyetlerini tanitıcı bir sayfa sunmalıdır", ve "web sitesi iyi bir üne sahip/popüler olmalıdır" olmak üzere beş maddeden oluşmaktadır. Web kalitesi ölçeğinin beşinci ve son faktörü olan "Hizmet etkileşimi" faktörü ise sırasıyla "web sitesinde doğrulanmış üye yorumları yer almalıdır", "web sitesi gizlilik ve güvenlik politikalarını açık biçimde ziyaretçilere sunmalıdır", "web sitesi ödeme güvenliği ve kişisel bilgilerin gizliliğini sağlayacak bir güvenlik programı kullanmalıdır", "web sitesi güncel olmalı ve bunun ziyaretçiler tarafından bilinmesi sağlanmalıdır" ve "web sitenin mobil uygulaması olmalıdır" olmak üzere beş maddeden oluşmaktadır. Analizler sonucu 36 maddeden oluşan, turistlerin online seyahat acenteleri aracilığıla seyahat satın almada turist memnuniyetlerini ve online seyahat acentelerinin web sitelerinin hizmet kalitesi kriterlerini ölçebilecek geçerli ve güvenilir bir ölçme aracı elde edilmiştir. 


\subsection{Verilerin Analizi}

Çalışmada yer alan iki ölçeğin güvenirlik analizlerini sağlamak amacıyla Cronbach alfa katsayısı hesaplanmış, geçerlik çalışması için ise Açıklayıcı Faktör Analizi (AFA) yapılmıştır.

Araştırma verilerinin normal dağılıma uyup uymadığını anlamak için Shapiro Wilks normalite testi yapılmıştır. Ayrıca, normallik testinin sonucuna göre normal dağılım göstermeyen veri gruplarının basıklık (kurtosis) ve çarpıklık (skewness) değerleri incelenmiş ve değişkenlerin normal dağllım sergilediği görülmüştür. Bu sebeple, verilerin çözümlenmesinde katılımcıların görüşleriyle ilgili farklılıkların olup olmadığı ve kontrol değişkenleri açısından anlamlı ilişkilerin bulunup bulunmadığının saptanması amacıyla T-testi (Independent Samples T-test), Tek Yönlü Varyans Analizi (One Way Anova), Scheffe (Çoklu Karşılaştırma Testi), Games-Howell gibi analiz yöntemleri kullanılmıştır. Yapılan tüm analizler $\% 95$ güven ve $\% 5$ hata payı ile test edilmiştir.

\section{BULGULAR VE YORUM}

Araştırmanın bulguları aşağıda sunulan başlıklar altında incelenmiştir.

\subsection{Katılımcılarla İlgili Demografik Bilgiler}

Katılımcılara ait demografik veriler incelendiğinde, katılımcıların \%52,5'ini kadın katılımcıların, \%47,5'ini ise erkek katılımcıların oluşturduğu saptanmıştır. Katılımcıların yaş dağılımına bakıldığında ise 18-29 ve 30-39 yaş grubundaki katılımcıların oranlarının eşit ve çoğunluktaki oranlar olduğu görülmektedir $(\% 24,5)$. 40-49 yaş grubunu oluşturan katılımcların oranının \%20,6; 50-59 yaş grubu katılımcılarının $\% 17,5$ ve son olarak 60 yaş ve üstü katılımcıların yaş oranlarının ise $\% 12,8$ olduğu görülmektedir.

Katılımcıların uyruklarına göre dağılımlarına bakıldığı zaman, \%13,6 ile en çok katılımcı uyruğun "Almanya" olduğu görülmektedir. \%12,3 ile ikinci sırada "İran", \%11,7 ile üçüncü sırada "Amerika", \%11,3 ile dördüncü sırada "İngiltere”, \%10,9 ile beşinci sırada "Irak", \%10,6 ile altıncı sırada "Rusya", \%10,4 ile yedinci sırada "Fransa", \%9,6 ile sekizinci sırada "Türkiye" ve \%9,6 ile dokuzuncu sirada "Diğer" grubu yer almaktadır.

Katılımcıların eğitim durumlarına göre dağılımlarına bakıldı̆̆ı zaman ise, $\% 39,6$ ile ilk sırada üniversite mezunlarının yer aldığı görülmektedir. İkinci sırada $\% 28,5$ ile lise mezunlarının, üçüncü sırada \%18,7 ile yüksek lisans/doktora mezunlarının, dördüncü sırada \%7,5 ile ilkokul mezunlarının ve son olarak \%0,9 ile diğer grubunun yer aldığı görülmektedir. Katılımcıların medeni durumlarına göre dağılımları incelendiğinde, katılımcıların \%75,5'inin evli, \%24,5'inin ise bekar olduğu görülmektedir.

Katılımcıların aylık gelir dağılımları incelendiğinde ise, \%30,4 ile ilk sırada 3001-4500\$ gelir grubunun yer aldı̆̆ görülmektedir. İkinci sırada \%22,8 ile 1001-3000\$ gelir grubunun, üçüncü sırada \%17,7 ile 4501-6000\$ gelir grubunun, dördüncü sırada 
$\% 11,7$ ile $1000 \$$ ve altı gelir grubunun, beşinci sırada $\% 9,4$ ile $7501 \$$ ve üstü gelir grubunun ve son olarak \%7,9 ile 6001-7500\$ gelir grubunun yer aldığı görülmektedir.

Katılımclara seyahat amaçları sorulduğunda ise, katılımcıların ilk sırada \%43,2 ile tatil/eğlence/boş zaman amacıyla seyahat ettikleri tespit edilmiştir. Katılımcıların $\% 21,1^{\prime}$ inin ise alışveriş amacıyla seyahat ettikleri saptanırken $\% 18,7^{\prime} \operatorname{sinin}$ iş (toplantı/konferans/ticaret), \%10,2'sinin aile/akraba/arkadaş ziyareti ve \%6,8'inin ise diğer amaçlarla seyahat ettikleri saptanmıştır. Katılımcıların tatil, iş vb. amaçlarla yaptıkları seyahat sıklıkları incelendiğinde \%53,2'sinin yılda birden fazla, \%29,6'sının yılda bir defa, \%10,8'sinin iki yılda bir ve \%6,4'ünün ise birkaç yılda bir seyahat ettikleri görülmektedir.

Katılımclara tatillerini genel olarak geçirdikleri yer sorulduğunda ise, katılımcların \%50,6'sının tatillerini genel olarak yurtiçi ve yurtdışında geçirdikleri görülmüştür. Katılımcıların \%33,2'sinin ise tatillerini genel olarak yurtiçinde geçirdikleri saptanırken, \%16,2'sinin tatillerini genel olarak yurtdışında geçirdikleri tespit edilmiştir.

Katılımclara İstanbul'daki konaklama süreleri sorulduğunda ise, katılımcılarının \%36'sının 4-7 gün; \%35,8'inin 7 günden fazla; $\% 24,5^{\prime}$ inin 1-3 gün ve \%3,6'sının ise günübirlik olarak İstanbul'da konakladıkları belirlenmiştir.

\subsection{Katılımcıların Genel Seyahat Satın Alma Alışkanlık ve Davranışlarına Yönelik Bulgu ve Yorumlar}

Katılımcıların genel seyahat satın alma alışkanlık ve davranışlarına ilişkin sorulan sorulardan, katılımcıların bir sonraki seyahat satın alma ihtiyaçlarında $\% 49,4^{\prime}$ ünün online seyahat acentelerini, \%29,9'ünün klasik seyahat acenteleri ve online seyahat acentelerinin her ikisini ve $\% 21,7$ 'ünün klasik seyahat acentelerini tercih edecekleri görülmüştür. Katılımcıların \%79,8'inin online seyahat acenteleri aracılığıyla seyahat satın almayı başkalarına önerdikleri; \%20,2'sinin ise online seyahat acenteleri aracılığıyla seyahat satın almayı başkalarına önermedikleri tespit edilmiştir. Katılımcıların \%56,0'sının klasik seyahat acenteleri aracılığıyla seyahat satın almayı başkalarına önerdikleri; \%44,0'ünün ise klasik seyahat acenteleri aracılığılyla seyahat satın almayı başkalarına önermedikleri saptanmıştır.

Katılımcılardan online seyahat acenteleri aracılığıyla seyahat satın alma deneyimlerini genel olarak değerlendirmeleri istendiğinde ise $\% 50,6$ 'sının online seyahat acenteleri aracılığıla seyahat satın almayı "çok iyi" olarak değerlendirdikleri; \%28,3'ünün online seyahat acenteleri aracılığıyla seyahat satın almayı "iyi" olarak değerlendirdikleri; \%9,6'sının online seyahat acenteleri aracılığıyla seyahat satın almay1 "kötü" olarak değerlendirdikleri; \%7,0'sinin online seyahat acenteleri aracılığıyla seyahat satın almayı "orta" olarak değerlendirdikleri ve \%4,5'inin ise online seyahat acenteleri aracılığıyla seyahat satın almayı "çok kötü" olarak değerlendirdikleri görülmüş̧ür. Katılımcılardan klasik seyahat acenteleri aracılığıyla seyahat satın alma deneyimlerini genel olarak değerlendirmeleri istendiğinde ise \%27,9'unun klasik seyahat acenteleri aracılığıyla seyahat satın almayı "çok iyi" olarak 
değerlendirdikleri; \%26,6'sının klasik seyahat acenteleri aracılığıyla seyahat satın almayı "iyi" olarak değerlendirdikleri; \%17,9'unun klasik seyahat acenteleri aracılığıyla seyahat satın almayı "orta" olarak değerlendirdikleri; \%14,2'sinin klasik seyahat acenteleri aracılığıyla seyahat satın almayı "kötü" olarak değerlendirdikleri ve \%13,4'ünün ise klasik seyahat acenteleri aracılığıyla seyahat satın almayı "çok kötü" olarak değerlendirdikleri görülmüştür.

Katılımcıların genel seyahat satın alma eğilimlerinin yer aldığı bu tablodaki istatistikler yorumlandığında; katılımcıların seyahat satın alma ihtiyaçlarında online seyahat acenteleri aracılığıla seyahat satın almayı, klasik seyahat acentelerine kıyasla daha çok tercih ettikleri; online seyahat acenteleri aracılığıyla seyahat satın almayı, klasik seyahat acentelerine kıyasla başkalarına daha çok önerdikleri ve online seyahat acenteleri aracılığıyla seyahat satın alma deneyimlerini klasik seyahat acentelerine kıyasla çok daha iyi bir deneyim olarak değerlendikleri görülmektedir.

\subsection{Katılımcıların Uyruklarına Göre Seyahat Satın Almada En Çok Tercih Ettikleri Online Seyahat Acentelerine Yönelik Bulgu ve Yorumlar}

Katılımcıların uyruklarına göre seyahat satın almada en çok tercih ettikleri online seyahat acentelerine ilişkin yer alan bilgiler incelendiğinde, online seyahat satın almada Almanya uyruklu turistlerin \%68,4'ünün Tui.com'u; \%18,7'sinin Booking.com'u; \%7,8'inin Expedia.com'u ve \%5,1'ini ise Tripadvisor.com'u tercih ettikleri görülmüştür.

Amerika uyruklu turistlerin ise online seyahat satın almada tercih ettikleri ilk acentenin \%30,2 ile Expedia.com olduğu saptanmıştır. İkinci sırada \%27,9 ile Booking.com'u; üçüncü sırada \%21,3 ile Hotwire.com'u; dördüncü sırada \%10,4 ile Orbitz.com'u ve beşinci sırada \%10,2 ile Kayak.com'u tercih ettikleri görülmüştür.

Fransa uyruklu turistlerin online seyahat satın almada tercih ettikleri acentelere bakıldığında ise ilk sırada \%29,8 ile Booking.com'u; ikinci sirada \%22,9 ile Tripadvisor.com'u; üçüncü sırada \%21,5 ile Expedia.com'u; dördüncü sırada \%16,2 ile Voyages-sncf.com'u ve son olarak beşinci sırada \%9,6 ile Travelzoo.com'u tercih ettikleri belirlenmiştir.

Irak uyruklu turistlerin online seyahat acentesi tercihlerine bakıldığı zaman ise ilk sırada \%34,6 ile Booking.com'un; ikinci sırada \%24,8 ile Tripadvisor.com'un; üçüncü sırada \%23,3 ile Airarabia.com'un; dördüncü sirada \%13,3 ile Otbtravels.com'un ve beşinci sırada \%4,1 ile Atlastours.net'in geldiği görülmüştür.

İngiltere uyruklu turistlerin online seyahat satın almada tercih ettikleri acentelere bakıldığında ise ilk sırada \%52,1 ile Thomson.co.uk'u; ikinci sırada \%41,8 ile Thomascook.com'u; üçüncü sırada \%3,1 ile Booking.com'u; dördüncü sırada \%1,9 ile Opodo.com'u ve \%1,1 ile Expedia.com'u tercih ettikleri belirlenmiştir.

İran uyruklu turistlerin online seyahat acentesi tercihlerine bakıldığ zaman ise ilk sirada \%31,9 ile Tripadvisor.com'un; ikinci sirada \%30,8 ile Booking.com'un; üçüncü sırada \%13,7 ile Gapatour.com'un; dördüncü sırada \%12,2 ile İransafar.co'nun ve beşinci sırada \%11,4 ile Uppersia.com'un geldiği görülmüştür. 
Türkiye uyruklu turistlerin ise online seyahat satın almada tercih ettikleri ilk acentenin \%28,1 ile Booking.com olduğu saptanmıştır. İkinci sırada \%26,3 ile Tatilsepeti.com'u; üçüncü sırada \%21,5 ile Etstur.com'u; dördüncü sırada \%18,9 ile Jollytur.com'u ve beşinci sırada \%5,2 ile Tatilbudur.com'u tercih ettikleri görülmüştür.

Rusya uyruklu turistlerin online seyahat satın almada tercih ettikleri acentelere bakıldığında ise ilk sirada \%48,8 ile Tez-tour.com'u; ikinci sırada \%35,9 ile Oktogo.ru.'yu; üçüncü sırada \%8,6 ile Booking.com'u; dördüncü sirada \%4,3 ile Travel.org'u ve son olarak beşinci sırada $\% 2,4$ ile Tripadvisor.com'u tercih ettikleri belirlenmiştir.

Diğer ülke uyruklarına mensup turistlerin online seyahat acentesi tercihlerine bakıldığı zaman ise ilk sırada \%39,9 ile Booking.com'un; ikinci sirada \%35,4 ile Tripadvisor.com'un; üçüncü sırada \%10,5 ile Zicasso.com'un; dördüncü sırada \%8,1 ile Yatra.com'un ve beşinci sırada \%6,1 ile Tnooz.com'un geldiği saptanmıştır.

Elde edilen bu tespitler, Booking.com, Expedia.com ve Tripadvisor.com gibi seyahat acenteciliğinde tüm dünya tarafından tercih edilen bir marka haline gelen acentelerin yanı sıra, Tui.com, Tez-tour.com gibi içinde bulundukları pazarda güçlü, etkin ve gelişmiş yerel firmaların da olduğunu ve katılımcılar tarafından uluslararası acenteler kadar yerel acentelerin de online seyahat satın almada tercih edildiğini göstermektedir.

\subsection{Katılımcıların E-Memnuniyet Ölçeğine İlişkin Betimleyici İstatistikler}

Klasik seyahat acenteleri ile kıyaslandığında katılımcıların \%94,3'ünün online seyahat acenteleri aracılığıyla ev-ofis bilgisayarları, tablet ve cep telefonlarından seyahat/tatil satın alabilmeye yüksek düzeyde, \%94,1'inin online seyahat acentelerine 7/24 ulaşabilme esnekliğine yüksek düzeyde, \%93,2'sinin online seyahat acentelerinin zaman tasarrufu sağlamasina yüksek düzeyde, \%91,7'sinin online seyahat acentelerinin uygun fiyat seçenekleri sunmasına yüksek düzeyde, $\% 88,5$ 'inin online seyahat acentelerinin doğrudan ve anında bilgi erişimi sağlamasına yüksek düzeyde, $\% 84,7^{\prime}$ sinin online seyahat acenteleri tarafından sunulan turizm hizmetlerinin (uçak biletleri, otel, vb.) sayısına yüksek düzeyde, \%82,7'sinin online seyahat acenteleri tarafından sunulan turizm hizmetlerinin (uçak biletleri, otel, vb) çeşitliliğine yüksek düzeyde, \%81,2'sinin online seyahat acenteleri tarafından sunulan turizm hizmetlerinin (uçak biletleri, otel, vb.) bilgi miktarına yüksek düzeyde, \%70,8'inin online seyahat acenteleri tarafından sunulan turizm hizmetlerinin (uçak biletleri, otel, vb.) bilgi kalitesine yüksek düzeyde, \%66,4'ünün online seyahat acenteleri aracılığıyla seyahat satın almada online işlemlerin kişisel mahremiyet ve gizliliğine orta düzeyde, $\% 64,9$ 'unun online seyahat acenteleri aracılı̆̆yla seyahat satın almada online işlemlerin güvenilirliğine orta düzeyde katıldıklarını belirtmişlerdir.

$\mathrm{Bu}$ bilgiler ışı̆̆ında, katılımcıların online seyahat acenteleri ve klasik seyahat acenteleri aracılığıyla seyahat satın alma memnuniyet düzeyleri arasında oransal olarak farklılıkların bulunduğu görülmüştür. Dolayısıyla $\mathbf{H}_{1}$ hipotezi kabul edilmiştir. 


\subsection{Katılımcıların Web Kalitesi Ölçeğine İlişkin Betimleyici İstatistikler}

Katılımcların \%95,8'i online seyahat acentelerinin web sitelerinin dizaynı ve sunuşunun çekici olması gerektiğini belirtmiştir. Katılımcıların \%95,7'si ise web sitelerinin ziyaretçilerine kullanım kolaylığı sağlamasını ve web sitelerinin güncel olması gerektiğini; \%95,5'i web sitelerinde ödeme güvenliği ve kişisel bilgilerin gizliliğini sağlayacak bir güvenlik programının kullanılması gerektiğini; \%94,8'i web sitelerinde site haritası, site içi arama motoru gibi uygulamaların bulunması gerektiğini; \%93,6'sı web sitelerinin seçenekleri sıralama/sınıflandırma özelliğinin bulunması ve web sitelerinin gizlilik ve güvenlik politikalarını açık bir biçimde ziyaretçilere sunmaları gerektiğini belirtmiştir. Katılımcların $\% 91,9^{\prime} u$ ise web sitelerinin iyi bir üne sahip/popüler olması gerektiğini; \%91,7'si web sitelerinin kesintisiz sayfalar ile sitede gezinme ve satın alma imkanı sunması gerektiğini; \%90,4'ü web sitelerinde kolay değişiklik yapma, iptal ve istek özelliğinin bulunması gerektiğini ve \%90,2'si ise web sitelerinin ziyaretçilerine uygun fiyat seçenekleri sunması gerektiğini belirtmiştir. Katılımcıların \%89,6'sı ise web sitelerinde çoklu dil seçeneğinin yer alması gerektiğini; \%89, $4^{\prime}$ ü web sitelerinin ziyaretçilerine acenteyi ve faaliyetlerini tanıtıcı bir sayfa sunmaları gerektiğini; \%88,5'i web sitelerinin ziyaretçilerine esnek rezervasyon imkanı sunması gerektiğini; $\% 87,6$ 'sı web sitelerinin bir iletişim sayfası ve çağrı merkezinin bulunması gerektiğini belirtmiştir.

Katılımcların \%87'si ise web sitelerinde sunulan hizmetlerle ilgili görsel bilgilerin (video, fotoğraf) yer alması gerektiğini; \%86,9'u web sitelerinin hızının yüksek olması gerektiğini; \%86,7'si web sitelerinde canlı destek hattının bulunması ve aktif olarak çalışması gerektiğini; \%86,2'si web sitelerinde tek bir işlemle tüm seyahat hizmetlerinin rezervasyon yapılabilmesi gerektiğini; $\% 85,3^{\prime} \ddot{u}$ web sitelerinin ziyaretçilerine farklı ödeme seçenekleri sunması gerektiğini belirtmiştir. Katılımcıların $\% 84,7$ 'si ise web sitelerinin sayfalarının görünüş ve tasarım olarak uyumlu/tutarlı olması gerektiğini; \%83,4'ü web sitelerinin mobil uygulamasının olması gerektiğini; $\% 80,4^{\prime}$ ü web sitelerinde sık sorulan sorular (SSS) sayfasının bulunması gerektiğini ve son olarak \%71,4'ü web sitelerinde doğrulanmış üye yorumlarının yer alması gerektiğini belirtmiştir.

\subsection{Katılımcıların Demografik Değişkenleri Açısından E-memnuniyet ve Web Kalitesi Ölçeklerinin Karşılaştırılması}

Cinsiyet, yaş, medeni durum, uyruk, eğitim düzeyi, aylık gelir gibi demografik değişkenler kapsamındaki farklılıkların, katılımcıların e-memnuniyet düzeyleri ve web sitesi hizmet kalitesi kriterleri açısından herhangi bir fark yaratıp yaratmadığı test edilmiştir. Bu amacı gerçekleştirmek üzere verilerin normal dağılım gösterdiği göz önünde bulundurularak, iki farklı grup altında toplanan değişkenler için "Bağımsız Örneklem T-Testi" ve ikiden fazla grup altında toplanan değişkenler için ise "Tek Yönlü Varyans Analizi" uygulanmıştır.

Katılımcıların cinsiyetleri açısından e-memnuniyet ve web kalitesi ölçeklerine ait alt boyutların ortalamaları arasındaki fark bağımsız örneklem t-testi aracılığıyla 
incelenmiş; ancak ortalamalar arasında 0.05 anlamlılık düzeyinde anlamlı bir fark tespit edilememiştir.

\subsection{Katılımcıların Medeni Durumu Açısından E-memnuniyet ve Web Kalitesi Ölçeklerine Ait Boyutların Karşılaştırılması}

Tablo 1. Medeni Durum Değişkenine Göre Boyutların Karşılaştırılması

(Bağımsız Örneklemeler T-testi)

\begin{tabular}{|c|c|c|c|c|c|c|c|}
\hline Boyutlar & $\begin{array}{l}\text { Medeni } \\
\text { Durum }\end{array}$ & $\mathbf{N}$ & Ort. & $\begin{array}{l}\text { Std. } \\
\text { Sapma }\end{array}$ & Df & $\mathbf{t}$ & $\mathbf{P}$ \\
\hline \multirow{2}{*}{$\begin{array}{l}\text { Ürün Satın Alma } \\
\text { Uygunluğu }\end{array}$} & Evli & 400 & 4,303 & ,5668 & \multirow{2}{*}{528} & \multirow{2}{*}{$-8,55$} & \multirow[t]{2}{*}{,000 } \\
\hline & Bekar & 130 & 4,700 & ,4186 & & & \\
\hline \multirow{2}{*}{$\begin{array}{l}\text { Ürün Satın Alma } \\
\text { Güvenilirliği }\end{array}$} & Evli & 400 & 2,974 & 7993 & \multirow{2}{*}{528} & \multirow{2}{*}{$-6,97$} & \multirow[t]{2}{*}{,000 } \\
\hline & Bekar & 130 & 3,438 & 6072 & & & \\
\hline \multirow{2}{*}{ Kullanılabilirlik } & Evli & 400 & 4,294 & ,5615 & \multirow[b]{2}{*}{528} & \multirow{2}{*}{$-6,66$} & \multirow{2}{*}{,016 } \\
\hline & Bekar & 130 & 4,627 & ,4729 & & & \\
\hline \multirow{3}{*}{ Teşvik Edicilik } & Evli & 400 & 3,960 & 7653 & \multirow{3}{*}{528} & \multirow{3}{*}{$-7,91$} & \multirow{3}{*}{,001 } \\
\hline & Bekar & 130 & 4,484 & 6157 & & & \\
\hline & Bekar & 130 & 4,478 & ,5441 & & & \\
\hline
\end{tabular}

Katılımcıların medeni durumlarına göre e-memnuniyet ölçeği altında yer alan "ürün satın alma uygunluğu" ve "ürün satın alma güvenilirliği" alt boyutları ile web kalitesi ölçeği altında yer alan "kullanılabilirlik" ve "teşvik edicilik" alt boyutları arasında 0.05 anlamlılık düzeyinde anlamlı bir farklılık tespit edilmiştir. Ememnuniyet ölçeği altında yer alan ürün satın alma uygunluğuna ilişkin veriler ele alındığında, bekar katılımcıların $(\bar{X}=4,700)$, evli katılımcılara $(\bar{X}=4,303)$ göre daha yüksek ortalamaya sahip oldukları görülmektedir. Bu verilerden yola çıkarak evli katılımcıların ürün satın alma uygunluğu algısının bekar katılımcılara göre daha düşük olduğu söylenebilir. E-memnuniyet ölçeği altında yer alan ürün satın alma güvenilirliğine ilişkin veriler ele alındığında ise yine bekar katılımcıların $(\bar{X}=3,438)$, evli katılımcılara $(\bar{X}=2,974)$ göre daha yüksek ortalamaya sahip oldukları görülmektedir. $\mathrm{Bu}$ verilerden yola çıkarak evli katılımcıların ürün satın alma güvenilirliği algılarının da ürün satın alma uygunluğu algılarında olduğu gibi bekar katılımcılara göre daha düşük olduğu söylenebilir. Web kalitesi ölçeği altında yer alan kullanılabilirlik $(\bar{X}=4,627)$ ve teşvik edicilik $(\bar{X}=4,484)$ algılarına ilişkin veriler ele alındığında, bekar katılımcıların evli katılımcılara göre her iki boyutta da daha yüksek ortalamaya sahip oldukları görülmektedir. Bu verilerden yola çıkarak, evli 
katılımcıların kullanılabilirlik ve teşvik edicilik algılarının bekar katılımcılara oranla daha düşük olduğu yorumu yapılabilir.

\subsection{Katılımcıların Uyruğuna Göre E-memnuniyet ve Web Kalitesi Ölçeklerine Ait Boyutların Karşılaştırılması}

Tablo 2. Uyruk Değişkenine Göre Boyutların Post Hoc Testi (Games-Howell)

\begin{tabular}{|c|c|c|c|c|c|c|c|}
\hline \multirow{2}{*}{ Boyutlar } & \multirow{2}{*}{ (I) Grup } & \multirow{2}{*}{ (J) Grup } & \multirow{2}{*}{$\begin{array}{c}\text { Farklar } \\
\text { Ortalaması } \\
\text { (I-J) }\end{array}$} & \multirow{2}{*}{$\begin{array}{l}\text { Standart } \\
\text { Hata }\end{array}$} & \multirow{2}{*}{ Anl. Düz. } & \multicolumn{2}{|c|}{ 95\% Güven Aralığ } \\
\hline & & & & & & Alt Sinir & Üst Sınır \\
\hline \multirow{5}{*}{$\begin{array}{l}\text { Ürün Satın Alma } \\
\text { Uygunluğu }\end{array}$} & \multirow{5}{*}{ Irak } & Almanya & $-39.355\left(^{*}\right)$ & 15.609 & .000 & -63.35 & -15.36 \\
\hline & & İngiltere & $-35.779\left(^{*}\right)$ & 14.109 & .001 & -61.84 & -09.72 \\
\hline & & Fransa & $-45.343\left(^{*}\right)$ & 13.219 & .000 & -72.47 & -18.22 \\
\hline & & Rusya & $-30.972\left(^{*}\right)$ & 15.355 & .026 & -59.87 & -02.07 \\
\hline & & Diğer & $-44.176\left(^{*}\right)$ & 14.480 & .000 & -72.02 & -16.33 \\
\hline \multirow{5}{*}{$\begin{array}{l}\text { Ürün Satın Alma } \\
\text { Güvenilirliği }\end{array}$} & \multirow{5}{*}{ Almanya } & Rusya & $-43.452\left(^{*}\right)$ & 13.316 & .037 & -85.49 & -01.42 \\
\hline & & İngiltere & $-35.779\left(^{*}\right)$ & 11.858 & .000 & -1.0355 & -28.67 \\
\hline & & Irak & $-66.111\left(^{*}\right)$ & 15.639 & .006 & -10.57 & -1.09 .31 \\
\hline & & İran & $-42.821\left(^{*}\right)$ & 11.871 & .013 & -80.29 & -05.35 \\
\hline & & Amerika & $-42.473\left(^{*}\right)$ & 12.642 & .028 & -82.35 & -02.60 \\
\hline \multirow{2}{*}{ Kullanılabilirlik } & \multirow{2}{*}{ Türkiye } & Irak & $-34.448\left(^{*}\right)$ & 08.048 & .001 & -08.94 & -59.96 \\
\hline & & İran & $-38.178\left(^{*}\right)$ & 11.064 & .022 & -03.14 & -73.22 \\
\hline \multirow{2}{*}{ Teşvik Edicilik } & \multirow{2}{*}{ Fransa } & Türkiye & $-50.410\left(^{*}\right)$ & 14.024 & .016 & -05.70 & -95.11 \\
\hline & & Irak & $-93.822\left({ }^{*}\right)$ & 11.545 & .000 & -57.24 & -1.30 .40 \\
\hline \multirow{6}{*}{ Hizmet Kalitesi } & \multirow{6}{*}{ Amerika } & Türkiye & $-69.774\left(^{*}\right)$ & 10.782 & .000 & -1.04 .02 & -35.53 \\
\hline & & Rusya & $-54.263\left({ }^{*}\right)$ & 11.458 & .000 & -90.55 & -17.98 \\
\hline & & İngiltere & $-53.132\left(^{*}\right)$ & 11.592 & .000 & -89.82 & -16.45 \\
\hline & & Irak & $-42.013\left({ }^{*}\right)$ & 11.684 & .014 & -78.99 & -05.03 \\
\hline & & Fransa & $-47.867\left(^{*}\right)$ & 11.729 & .003 & -84.99 & -10.74 \\
\hline & & Diğer & $-79.125\left(^{*}\right)$ & 10.613 & .000 & -1.12 .86 & -45.39 \\
\hline
\end{tabular}


Tablo 2. Uyruk Değişkenine Göre Boyutların Post Hoc Testi (Games-Howell)-Devamı

\begin{tabular}{|c|c|c|c|c|c|c|c|}
\hline \multirow{2}{*}{ Boyutlar } & \multirow{2}{*}{ (I) Grup } & \multirow{2}{*}{ (J) Grup } & \multirow{2}{*}{$\begin{array}{c}\text { Farklar } \\
\text { Ortalamas1 } \\
\text { (I-J) }\end{array}$} & \multirow{2}{*}{ Standart Hata } & \multirow{2}{*}{ Anl. Düz. } & \multicolumn{2}{|c|}{ 95\% Güven Aralığ } \\
\hline & & & & & & Alt Sinır & Üst Sınır \\
\hline \multirow{3}{*}{ Verimlilik } & \multirow{3}{*}{ Fransa } & Türkiye & $-27.522\left(^{*}\right)$ & 08.235 & .031 & -01.43 & -53.62 \\
\hline & & Rusya & $-38.214\left(^{*}\right)$ & 08.914 & .013 & -04.07 & -60.54 \\
\hline & & Diğer & $-41.014\left(^{*}\right)$ & 08.729 & .000 & -13.34 & -68.69 \\
\hline \multirow{3}{*}{$\begin{array}{c}\text { Hizmet } \\
\text { Etkileşimi }\end{array}$} & \multirow{3}{*}{ İngiltere } & İran & $-55.538\left(^{*}\right)$ & 10.946 & .000 & -20.91 & -90.17 \\
\hline & & Amerika & $-48.903\left(^{*}\right)$ & 10.891 & .001 & -14.42 & -83.38 \\
\hline & & Irak & $-42.038\left(^{*}\right)$ & 08.538 & .011 & -22.56 & -31.48 \\
\hline
\end{tabular}

Uyruk değişkenine göre grupların (uyrukların) ikili karşılaştırmalarında grup içi varyansların homojen olmamasından dolayı Games-Howel post hoc testi kullanılmıştır (Games, 1971). Games-Howell post hoc testinin sonuçlarına göre; Web kalitesi ölçeğinin kullanılabilirlik, teşvik edicilik, hizmet kalitesi, verimlilik ve hizmet etkileşimi alt boyutları arasında da katılımcıların uyruk değişkenine göre anlamlı farklılıklar olduğu görülmüştür. Farklılıklar incelendiğinde uyruğu Türkiye olan katılımcıların "kullanılabilirlik" düzeylerinin, uyruğu Irak ve İran olan katılımcılara oranla daha yüksek olduğu saptanırken, uyruğu Fransa olan katılımcıların "teşvik edicilik" düzeylerinin, uyruğu Türkiye ve Irak olan katılımcılara kıyasla daha yüksek olduğu tespit edilmiştir. Aynı şekilde, uyruğu Amerika olan katılımcıların "hizmet kalitesi" düzeylerinin, uyruğu Türkiye, Rusya, İngiltere, Irak, Fransa ve diğer olan katılımcılara oranla daha yüksek olduğu görülürken, uyruğu Fransa olan katılımcıların "verimlilik" düzeylerinin; Türkiye, Rusya ve Diğer olan katılımcılara kıyasla daha yüksek olduğu saptanmıştır. Son olarak uyruğu İngiltere olan katılımcıların "hizmet etkileşimi" düzeylerinin, uyruğu İran, Irak ve Amerika olan katılımcılara oranla daha yüksek olduğu tespit edilmiştir. 


\subsection{Katılımcıların Eğitim Durumu Açısından E-memnuniyet ve Web Kalitesi Ölçeklerine Ait Boyutların Karşılaştırılması}

Tablo 3. Eğitim Durumu Değişkenine Göre Boyutların Post Hoc Testi (Tukey Testi)

\begin{tabular}{|c|c|c|c|c|c|c|}
\hline Boyutlar & (I) Grup & (J) Grup & Ort. Fark (I-J) & Ort. & $\begin{array}{l}\text { Standart } \\
\text { hata }\end{array}$ & $\begin{array}{l}\text { Anl. } \\
\text { Düz. }\end{array}$ \\
\hline \multirow{2}{*}{ Kullanılabilirlik } & \multirow{2}{*}{ İlkokul } & Üniversite &,$- 36095^{*}$ & 4,4810 & 09098 & ,001 \\
\hline & & $\begin{array}{c}\text { Yüksek } \\
\text { Lisans/Doktora }\end{array}$ &,$- 47596^{*}$ & 4,5960 & ,09881 & ,000 \\
\hline \multirow[b]{2}{*}{ Teşvik Edicilik } & \multirow[b]{2}{*}{ İlkokul } & Üniversite &,$- 88294^{*}$ & 4,3079 & 12039 &, 000 \\
\hline & & $\begin{array}{c}\text { Yüksek } \\
\text { Lisans/Doktora }\end{array}$ &,$- 97904^{*}$ & 4,4040 & 13074 & ,000 \\
\hline \multirow[t]{2}{*}{ Hizmet Kalitesi } & \multirow{2}{*}{ İlkokul } & Üniversite &, $88571^{*}$ & 4,3060 & ,28437 &, 024 \\
\hline & & $\begin{array}{c}\text { Yüksek } \\
\text { Lisans/Doktora }\end{array}$ &, $83586^{*}$ & 4,2082 & 11774 & ,032 \\
\hline Verimlilik & Ortaokul & Üniversite &,$- 78095^{*}$ & 4,3576 & 11017 & ,000 \\
\hline
\end{tabular}

Eğitim durumu değişkenine göre grup varyansların homojen olduğu ( $p>0.05)$ alt boyutlar arasındaki farklılıkları tespit edebilmek amaciyla bu boyutlara 'Tukey testi' uygulanmıştır. Tablo incelendiğinde, ilköğretim mezunu katılımcıların "kullanılabilirlik", "teşvik edicilik" ve "hizmet kalitesi" algılarının üniversite ve yüksek lisans/doktora mezunu katılımcılara kıyasla daha düşük olduğu görülmüştür. Diğer bir ifade ile ilkokul mezunlarının, "kullanılabilirlik", "teşvik edicilik", "hizmet kalitesi" alt boyutlarının algılarını, üniversite ve yüksek lisans/doktora mezunlarına göre daha düşük oranda "önemli" buldukları söylenebilir. Ayrıca "verimlilik" alt boyutunda ortaokul ve üniversite mezunları arasında da anlamlı farklılıkların olduğu saptanmıştır. Tablo incelendiğinde, ortaokul mezunu katılımcıların "verimlilik" alt boyutu algılarının üniversite mezunu katılımcılara oranla daha düşük olduğu tespit edilmiştir. Bu tespite göre, ilkokul mezunlarının "verimlilik" unsurlarını, üniversite ve yüksek lisans/doktora mezunlarına göre daha düşük oranda önemli buldukları yorumu yapilabilir. 
Tablo 4. Eğitim Durumu Değişkenine Göre Boyutların Post Hoc Testi (Games-Howell)

\begin{tabular}{|c|c|c|c|c|c|c|c|}
\hline \multirow{2}{*}{ Boyutlar } & \multirow{2}{*}{ (I) Grup } & \multirow{2}{*}{ (J) Grup } & \multirow{2}{*}{$\begin{array}{c}\text { Farklar } \\
\text { Ortalaması } \\
\text { (I-J) }\end{array}$} & \multirow{2}{*}{$\begin{array}{c}\text { Standart } \\
\text { Hata }\end{array}$} & \multirow{2}{*}{$\begin{array}{l}\text { Anl. } \\
\text { Düz. }\end{array}$} & \multicolumn{2}{|c|}{ 95\% Güven Aralığ1 } \\
\hline & & & & & & Alt Sinir & Üst Sınır \\
\hline \multirow{3}{*}{$\begin{array}{l}\text { Ürün Satın } \\
\text { Alma } \\
\text { Uygunluğu }\end{array}$} & \multirow{3}{*}{ İlkokul } & Lise &,$- 66512^{*}$ & 15488 & ,001 & $-1,1220$ &,- 2082 \\
\hline & & Üniversite & $-1,13810^{*}$ & , 14676 & ,000 & $-1,5745$ &,- 7017 \\
\hline & & $\begin{array}{c}\text { Yüksek } \\
\text { Lisans/Doktora }\end{array}$ & $-1,04613^{*}$ & 15519 & ,000 & $-1,5039$ &,- 5884 \\
\hline \multirow{3}{*}{$\begin{array}{l}\text { Ürün Satın } \\
\text { Alma } \\
\text { Güvenilirliği }\end{array}$} & \multirow{3}{*}{ İlkokul } & Lise &,$- 61071^{*}$ & 13971 &, 000 & $-1,1517$ &,- 2947 \\
\hline & & Üniversite &,$- 69785^{*}$ & 14337 & ,000 & $-1,2470$ &,- 3737 \\
\hline & & $\begin{array}{c}\text { Yüksek } \\
\text { Lisans/Doktora }\end{array}$ &,$- 72321^{*}$ & 13971 & ,000 & 2947 & 1,1517 \\
\hline \multirow{3}{*}{$\begin{array}{c}\text { Hizmet } \\
\text { Etkileşimi }\end{array}$} & \multirow{3}{*}{ İlkokul } & Lise &,$- 61071^{*}$ & 13971 & ,000 & $-1,1517$ &,- 2947 \\
\hline & & Üniversite &,$- 69785^{*}$ & , 14337 & ,000 & $-1,2470$ &,- 3737 \\
\hline & & $\begin{array}{c}\text { Yüksek } \\
\text { Lisans/Doktora }\end{array}$ &,$- 72321^{*}$ & 13971 &, 000 & 2947 & 1,1517 \\
\hline
\end{tabular}

Grupların (uyrukların), eğitim durumu değişkenine göre ikili karşılaştırmalarında grup içi varyansların homojen olmamasından dolayı GamesHowel post hoc testi kullanılmıştır. Games-Howell post hoc testi sonucuna göre; ilkokul mezunu katılımcıların "ürün satın alma uygunluğu", "ürün satın alma güvenilirliği" ve "hizmet etkileşimi" alt boyutlarına verdikleri cevapların ortalamaları arasında anlamlı bir farklılık olduğu görülmüştür. Farkın kaynağı incelendiğinde, ilkokul mezunu katılımcıların, "ürün satın alma uygunluğu", "ürün satın alma güvenilirliği" ve "hizmet etkileşimi" düzeylerinin lise, üniversite ve yüksek lisans/doktora mezunlarına oranla daha düşük olduğu sonucuna ulaşılmıştır. Diğer bir ifade ile ilkokul mezunlarının "ürün satın alma uygunluğu", "ürün satın alma güvenilirliği" ve "hizmet etkileşimi" alt boyutları altında yer alan ifadeleri; lise, üniversite ve yüksek lisans/doktora mezunlarına göre daha düşük oranda önemli buldukları söylenebilir. 


\subsection{Katılımcıların Yaşı Açısından E-memnuniyet ve Web Kalitesi Ölçeklerine Ait Boyutların Karşılaştırılması}

Tablo 5. Yaş Değişkenine Göre Boyutların Post Hoc Testi (Games-Howell)

\begin{tabular}{|c|c|c|c|c|c|c|c|}
\hline \multirow{2}{*}{ Boyutlar } & \multirow{2}{*}{ (I) Grup } & \multirow{2}{*}{ (J) Grup } & \multirow{2}{*}{$\begin{array}{c}\text { Farklar } \\
\text { Ortalaması } \\
\text { (I-J) }\end{array}$} & \multirow{2}{*}{ Standart Hata } & \multirow{2}{*}{$\begin{array}{l}\text { Anl. } \\
\text { Düz. }\end{array}$} & \multicolumn{2}{|c|}{ 95\% Güven Aralığı } \\
\hline & & & & & & Alt Sinır & Üst Sınır \\
\hline \multirow{2}{*}{$\begin{array}{l}\text { Ürün Satın Alma } \\
\text { Uygunluğu }\end{array}$} & \multirow{2}{*}{$18-29$} & $50-59$ &, $50977^{*}$ & 06645 & ,000 & ,3264 & 6932 \\
\hline & & 60 ve üstü &, $75212^{*}$ & ,09633 & ,000 & ,4837 & 1,0205 \\
\hline \multirow{2}{*}{$\begin{array}{l}\text { Ürün Satın Alma } \\
\text { Güvenilirliği }\end{array}$} & \multirow{2}{*}{$30-39$} & $50-59$ & $46330^{*}$ & 10619 & ,000 & 1704 & 7562 \\
\hline & & 60 ve üstü &, $85535^{*}$ & 11877 & ,000 &, 5260 & 1,1847 \\
\hline \multirow{2}{*}{ Kullanılabilirlik } & \multirow{2}{*}{$18-29$} & $50-59$ &, $34065^{*}$ & 06401 & ,000 & 1642 &, 5171 \\
\hline & & 60 ve üstü & ,60706* & 10552 & ,000 & ,3131 & 9010 \\
\hline \multirow{3}{*}{ Teşvik Edicilik } & \multirow{3}{*}{$40-49$} & $18-29$ &,$- 43788^{*}$ & 11079 & ,001 &,- 7455 &,- 1302 \\
\hline & & $50-59$ & $43090^{*}$ & 10562 & 001 & 1401 & 7217 \\
\hline & & 60 ve üstü & ,72090* & 12403 & ,000 & ,3778 & 1,0640 \\
\hline \multirow{3}{*}{ Hizmet Kalitesi } & \multirow{3}{*}{$40-49$} & $30-39$ &,$- 31805^{*}$ & , 10862 & ,034 &,- 6206 &,- 0155 \\
\hline & & $50-59$ &,$- 93831^{*}$ & 11384 & ,000 & $-1,2545$ &,- 6222 \\
\hline & & 60 ve üstü &,$- 89216^{*}$ & 11444 & ,000 & $-1,2099$ &,- 5745 \\
\hline \multirow{3}{*}{ Verimlilik } & \multirow{3}{*}{$18-29$} & $40-49$ & $21474^{*}$ & ,07135 &, 024 & ,0182 & ,4112 \\
\hline & & $50-59$ & $22428^{*}$ & 06841 & 011 & ,0357 & 4128 \\
\hline & & 60 ve üstü &, $31805^{*}$ & 10862 & 034 & ,0155 & 6206 \\
\hline \multirow{3}{*}{ Hizmet Etkileşimi } & \multirow{3}{*}{$40-49$} & $18-29$ &, $55041^{*}$ & 09957 & ,000 & 2733 & 8275 \\
\hline & & $50-59$ & ,28733* & ,06851 & ,000 & ,0985 & ,4762 \\
\hline & & 60 ve üstü &, $59195^{*}$ & 09991, & ,000 & ,3140 & 8699 \\
\hline
\end{tabular}

Yaş değişkenine göre grupların (uyrukların) ikili karşılaştırmalarında grup içi varyanslarin homojen olmamasindan dolayı Games-Howel post hoc testi kullanılmıştır. Tablo incelendiğinde, 18-29 yaş grubundaki katılımcıların, "ürün satın alma uygunluğu" ve "kullanılabilirlik" algılarının 50-59 ve 60 ve üstü yaş grubundaki katılımclara kıyasla daha yüksek olduğu görülmüştür. Diğer bir ifade ile 18-29 yaş grubu katılımcıların, "ürün satın alma uygunluğu" ve "kullanılabilirlik" alt boyutları altında yer alan ifadeleri, 50-59 ve 60 ve üstü yaş grubu katılımcılara kıyasla daha yüksek oranda "önemli" buldukları söylenebilir. Ayrıca "verimlilik" alt boyutunda 1829 yaş grubundaki katılımcılar ile 40-49, 50-59 ve 60 ve üstü yaş grubu katılımcılar arasında da anlamlı farklılıkların olduğu saptanmıştır. Tablo incelendiğinde, 18-29 yaş grubundaki katılımcların "verimlilik" alt boyutu algılarının üniversite mezunu katılımcılara oranla daha yüksek olduğu tespit edilmiştir. Bu tespite göre, 18-29 yaş grubundaki katılımcıların, "verimlilik" alt boyutu altında yer alan ifadeleri, üniversite 
ve yüksek lisans/doktora mezunlarına göre daha yüksek oranda "önemli” buldukları yorumu yapılabilir.

40-49 yaş grubundaki katılımcıların, "teşvik edicilik", "hizmet etkileşimi" algılarının 18-29, 50-59 ve 60 ve üstü yaş grubundaki katılımcılara kıyasla daha yüksek olduğu görülmüştür. Diğer bir ifade ile 40-49 yaş grubu katılımcıların, "teşvik edicilik" ve "hizmet etkileşimi" alt boyutları altında yer alan ifadeleri, 18-29, 50-59 ve 60 ve üstü yaş grubu katılımcılara göre daha yüksek oranda "önemli" buldukları söylenebilir. "Hizmet kalitesi" alt boyutunda ise 40-49 yaş grubundaki katılımcllar ile 30-39, 50-59 ve 60 ve üstü yaş grubu katılımcılar arasında da anlamlı farklılıkların olduğu saptanmıştır. Farklılıklar incelendiğinde, 40-49 yaş grubundaki katılımcıların "hizmet kalitesi" alt boyutu algılarının üniversite mezunu katılımclara oranla daha yüksek olduğu tespit edilmiştir. Bu tespite göre, 40-49 yaş grubundaki katılımcıların, "hizmet kalitesi" alt boyutu altında yer alan ifadeleri, 30-39, 50-59 ve 60 ve üstü yaş grubu katılımcılara göre daha yüksek oranda "önemli" buldukları yorumu yapılabilir. Son olarak 30-39 yaş grubundaki katılımcıların "ürün satın alma güvenilirliği” algılarının, 50-59 ve 60 ve üstü yaş grubundaki katılımcılara kıyasla daha yüksek olduğu saptanmıştır. Bu sonuca göre, 30-39 yaş grubundaki katılımcıların, “ürün satın alma güvenilirliği" alt boyutu altında yer alan ifadeleri, 50-59 ve 60 ve üstü yaş grubundaki katılımcılara göre daha yüksek oranda önemli buldukları söylenebilir.

\subsection{Katılımcıların Aylık Geliri Açısından E-memnuniyet ve Web Kalitesi Ölçeklerine Ait Boyutların Karşılaştırılması}

Tablo 6. Aylık Gelir Değişkenine Göre Boyutların Post Hoc Testi (Tukey Testi)

\begin{tabular}{|c|c|c|c|c|c|c|}
\hline Boyutlar & (I) Grup & (J) Grup & Ort. Fark (I-J) & Ort. & $\begin{array}{c}\text { Standart } \\
\text { hata }\end{array}$ & $\begin{array}{l}\text { Anl. } \\
\text { Düz. }\end{array}$ \\
\hline \multirow{3}{*}{$\begin{array}{c}\text { Ürün Satın Alma } \\
\text { Uygunluğu }\end{array}$} & \multirow{3}{*}{$1000 \$$ ve alt 1} & $4501-6000 \$$ &,$- 28104^{*}$ & 4,5372 & ,07481 & ,003 \\
\hline & & $6001-7500 \$$ &,$- 33309^{*}$ & 4,5893 & ,09745 & 009 \\
\hline & & 7501\$ ve üstü &,$- 42630^{*}$ & 4,6825 & ,09148 & ,000 \\
\hline \multirow{2}{*}{$\begin{array}{l}\text { Ürün satın alma } \\
\text { güvenilirliği }\end{array}$} & \multirow{2}{*}{$1001-3000 \$$} & $6001-7500 \$$ & ,37403* & 3,0704 & 10065 & ,004 \\
\hline & & 7501\$ ve üstü &, $35486^{*}$ & 3,1702 & ,08277 & ,000 \\
\hline \multirow{2}{*}{ Hizmet Kalitesi } & \multirow{2}{*}{$1000 \$$ ve alt1 } & $3001-4500 \$$ & ,39211* & 4,2127 & ,09351 & , 000 \\
\hline & & $4501-6000 \$$ & ,30431* & 4,3005 & 10235 & ,036 \\
\hline \multirow{2}{*}{ Verimlilik } & \multirow{2}{*}{$7501 \$$ ve üstü } & $1000 \$$ ve altı &,$- 13626^{*}$ & 4,6048 & 10943 & ,008 \\
\hline & & $1001-3000 \$$ &,$- 13293^{*}$ & 4,3740 & 09679 & ,036 \\
\hline
\end{tabular}

Aylık gelir değişkenine göre grup varyansların homojen olduğu ( $>>0.05)$ alt boyutlar arasındaki farklılıkları tespit edebilmek amacıyla bu boyutlara 'Tukey testi' uygulanmıştır. Tablo incelendiğinde, $1000 \$$ ve altı aylık gelire sahip katılımcıların, 
“ürün satın alma uygunluğu” algılarının 4501-6000\$, 6001-7500\$ ve 7501\$ ve üstü aylık gelire sahip katılımcılara kıyasla daha düşük olduğu görülmüştür. Diğer bir ifade ile $1000 \$$ ve altı aylık gelire sahip katılımcıların, "ürün satın alma uygunluğu" alt boyutunun algılarını, 4501-6000\$, 6001-7500\$ ve 7501\$ ve üstü aylık gelire sahip katılımcılara göre daha düşük oranda önemli buldukları söylenebilir.

“Ürün satın alma güvenilirliği” alt boyutunda 1001-3000\$ aylık gelire sahip katılımcılar arasında da anlamlı farklılıkların olduğu saptanmıştır. Tablo incelendiğinde, 1001-3000\$ aylık gelire sahip katılımcıların "ürün satın alma güvenilirliği" alt boyutu algilarının 6001-7500\$ ve 7501\$ ve üstü aylı gelire sahip katılımcılara oranla daha düşük olduğu tespit edilmiştir. Bu tespite göre, 1001-3000\$ aylık gelire sahip katılımcıların "ürün satın alma güvenilirliği" alt boyutunun unsurlarını, 6001-7500\$ ve 7501\$ ve üstü aylık gelire sahip katılımcılara göre daha düşük oranda önemli buldukları yorumu yapılabilir.

Alt boyutlar arasında aylık gelir değişkenine göre ortaya çıkan diğer bir farklılığın ise, $1000 \$$ ve altı aylık gelire sahip katılımcıların "hizmet kalitesi" algılarının 3001-4500\$ ve 4501-6000\$ aylık gelire sahip katılımcılara kıyasla daha düşük olduğu görülmektedir. Diğer bir ifade ile 1000\$ ve altı aylık gelire sahip katılımcıların, "hizmet kalitesi" alt boyutunun algılarını, 3001-4500\$ ve 4501-6000\$ aylik gelire sahip katılımcılara göre daha düşük oranda önemli buldukları söylenebilir.

Son olarak 7501\$ ve üstü aylık gelire sahip katılımcıların "verimlilik" alt boyutunda $1000 \$$ ve altı ve 1001-3000\$ aylık gelire sahip katılımclar arasında da anlamlı farklılıkların olduğu saptanmıştır. Farklılıklar incelendiğinde, 7501\$ ve üstü aylık gelire sahip katılımcıların "verimlilik" alt boyutu algılarının $1000 \$$ ve altı ve $1001-$ 3000\$ aylık gelire sahip katılımcılara oranla daha yüksek olduğu tespit edilmiştir. Bu tespite göre, 7501\$ ve üstü aylık gelire sahip katılımcıların "verimlilik" alt boyutu altında yer alan ifadeleri, $1000 \$$ ve altı ve $1001-3000 \$$ aylık gelire sahip katılımcilara kıyasla daha yüksek oranda önemli buldukları yorumu yapılabilir.

\subsection{Web Kalitesi ve E-memnuniyet Arasındaki İlişki}

E-memnuniyet ve web kalitesi kavramları arasındaki ilişkinin belirlenebilmesi için boyutların arasındaki ilişkinin belirlenebilmesi için tüm kavramları oluşturan boyutlar (faktörler) arasında 'pearson korelasyon' analizi yapılmıştır. Korelasyon analizine ait sonuçlar aşağıdaki tabloda yer almaktadır. 
Tablo 7. Korelasyon Analizi

\begin{tabular}{|c|l|c|c|c|c|c|c|c|c|c|}
\hline & Boyutlar & $\bar{X}$ & S.S. & $\mathbf{1}$ & $\mathbf{2}$ & $\mathbf{3}$ & $\mathbf{4}$ & $\mathbf{5}$ & $\mathbf{6}$ & $\mathbf{7}$ \\
\hline $\mathbf{1}$ & $\begin{array}{l}\text { Ürün Satın } \\
\text { Ulma } \\
\text { Uygunluğu }\end{array}$ & 4,40 &, 56065 & $\mathbf{1}$ & & & & & & \\
\hline $\mathbf{2}$ & $\begin{array}{l}\text { Ürün Satın } \\
\text { Alma } \\
\text { Güvenilirliği }\end{array}$ & 3,08 &, 78221 &, $69947^{* *}$ & $\mathbf{1}$ & & & & & \\
\hline $\mathbf{3}$ & Kullanilabilirlik & 4,37 &, 55952 &, $588^{* *}$ &, $446^{* *}$ & $\mathbf{1}$ & & & & \\
\hline $\mathbf{4}$ & Teşvik Edicilik & 4,08 &, 76496 &, $868^{* *}$ &, $791^{* *}$ &, $498^{* *}$ & $\mathbf{1}$ & & & \\
\hline $\mathbf{5}$ & Hizmet Kalitesi & 4,32 &, 63358 &, $266^{* *}$ &, $090^{*}$ &, $401^{* *}$ &, $194^{* *}$ & $\mathbf{1}$ & & \\
\hline $\mathbf{6}$ & Verimlilik & 4,26 &, 57618 &, $347^{* *}$ &, $193^{* *}$ &, $443^{* *}$ &, $267^{* *}$ &, $594^{* *}$ & $\mathbf{1}$ & \\
\hline $\mathbf{7}$ & $\begin{array}{l}\text { Hizmet } \\
\text { Etkileşimi }\end{array}$ & 4,28 &, 55223 &, $542^{* *}$ &, $495^{* *}$ &, $506^{* *}$ &, $519^{* *}$ &, $193^{* *}$ &, $390^{* *}$ & $\mathbf{1}$ \\
\hline
\end{tabular}

Korelasyon katsayısı olan r, iki değişken arasındaki ilişkinin ölçüsüdür ve -1 ve +1 arasında değişim gösterir. $\mathrm{r}$ değeri 0.00-0.25 değerleri arasında ise çok zayıf ilişki; 0.26-0.49 değerleri arasında ise zayıf ilişki; 0.50-0.69 değerleri arasında ise orta ilişki; 0.70-0.89 değerleri arasında yüksek ilişki; 0.90-1.00 arasında ise değişkenler arasında çok yüksek ilişki var demektir (Subaşı, 2014). Buna göre, Tablo 7'de yer alan değişkenler arasındaki ilişkilere bakıldığında; e-memnuniyet ölçeğinin boyutlarından; ürün satın alma uygunluğu ile ürün satın alma güvenilirliği $(\mathrm{r}=, 647 ; \mathrm{p}<0.01)$, kullanılabilirlik $(\mathrm{r}=, 588 ; \mathrm{p}<0.01)$, teşvik edicilik $(\mathrm{r}=, 868 ; \mathrm{p}<0.01)$, hizmet kalitesi $(\mathrm{r}=$ ,266; $\mathrm{p}<0.01)$, verimlilik $(\mathrm{r}=, 347 ; \mathrm{p}<0.01)$ ve hizmet etkileşimi $(\mathrm{r}=, 542 ; \mathrm{p}<0.01)$ arasında anlamlı ve pozitif yönlü bir ilişki tespit edilmiştir. Web kalitesi ölçeğinin boyutlarından kullanılabilirlik ile ürün satın alma güvenilirliği $(r=, 446 ; p<0.01)$; teşvik edicilik $(r=$ ,791; $\mathrm{p}<0.01)$; hizmet kalitesi $(\mathrm{r}=, 090 ; \mathrm{p}<0.05)$; verimlilik $(\mathrm{r}=, 193 ; \mathrm{p}<0.01)$ ve hizmet etkileşimi $(r=495 ; p<0.01)$ arasında da anlamlı ve pozitif yönlü bir ilişki tespit edilmiştir. Web kalitesi ölçeğinin bir diğer boyutu olan teşvik edicilik ile kullanılabilirlik $(\mathrm{r}=, 498 ; \mathrm{p}<0.01)$, hizmet kalitesi $(\mathrm{r}=, 401 ; \mathrm{p}<0.01)$, verimlilik $(\mathrm{r}=, 443$; $\mathrm{p}<0.01)$ ve hizmet etkileşimi $(\mathrm{r}=, 506 ; \mathrm{p}<0.01)$ arasında anlamlı ve pozitif yönlü bir ilişki tespit edilmiştir. Bütün bu ilişkiler incelendiğinde katılımclların web sitesi hizmet kalitesi kriterleri ile e-memnuniyet düzeyleri cinsiyet haricideki bütün demografik değişkenlere göre farklılık gösteresi nedeniyle $\mathbf{H}_{2}$ ve $\mathbf{H}_{3}$ kabul edilmiştir.

Web kalitesi ölçeğinin boyutlarından; hizmet kalitesi ve teşvik edicilik ( $\mathrm{r}=, 194$; $\mathrm{p}<0.01)$, verimlilik $(\mathrm{r}=, 267 ; \mathrm{p}<0.01)$ ve hizmet etkileşimi $(\mathrm{r}=, 519 ; \mathrm{p}<0.01)$ arasında anlamlı ve pozitif yönlü bir ilişkinin olduğu görülmüştür. Web kalitesi ölçeğinin boyutlarından verimlilik ve hizmet kalitesi $(r=$,594; $\mathrm{p}<0.01)$, hizmet etkileşimi $(\mathrm{r}=$,193; 
p<0.01); arasında da anlamlı ve pozitif yönlü bir ilişki tespit edilmiştir. Web kalitesi ölçeğinin son boyutu olan hizmet etkileşimi ile verimlilik boyutunun arasında ise $(r=$ ,390; $\mathrm{p}<0.01$ ) anlamlı ve pozitif yönlü bir ilişki tespit edilmiştir. Dolayısıyla $\mathbf{H}_{4}$ hipotezi kabul edilmiştir.

Tablo 8. Hipotez Testi Sonuçları

\begin{tabular}{|l|l|}
\hline \multicolumn{1}{|c|}{ HIPOTEZ } & SONUÇ \\
\hline $\begin{array}{l}\text { H: Katılımcıların online seyahat acenteleri ve klasik seyahat acenteleri } \\
\text { aracılığıyla seyahat satın alma memnuniyet düzeyleri arasında istatistiksel } \\
\text { olarak anlamlı farklılıklar vardır. }\end{array}$ & Desteklendi \\
\hline $\begin{array}{l}\text { H: Katılımcıların demografik değişkenleri ile e-memnuniyet düzeyleri } \\
\text { arasında istatistiksel olarak anlamlı farklılıklar vardır. }\end{array}$ & Desteklendi \\
\hline $\begin{array}{l}\text { H}_{3}: \text { Katılımcların demografik değişkenleri ile web sitesi hizmet kalitesi } \\
\text { kriterleri arasında istatistiksel olarak anlamlı farklılıklar vardır. }\end{array}$ & Desteklendi \\
\hline $\begin{array}{l}\text { H: Katılımcıların e-memnuniyet düzeyleri ile web sitesi hizmet kalitesi } \\
\text { kriterleri arasında istatistiksel olarak anlamlı bir ilişki vardır. }\end{array}$ & Desteklendi \\
\hline
\end{tabular}

$\mathrm{Bu}$ bulgular sonucunda, katılımcların e-memnuniyet ve web sitesi hizmet kalitesi kriterleri arasında pozitif ve anlamlı bir ilişkinin olduğu görülmüştür. Online seyahat acenteleri aracılığıly ürün satın alma uygunluğu ve ürün satın alma güvenilirliği ile online seyahat acentelerinin web sitelerinin kullanılabilirlik, teşvik edicilik, hizmet kalitesi, verimlilik ve hizmet etkileşimi unsurlarının, turistik tüketicilerin online seyahat acenteleri aracilı̆̆ıyla seyahat satın alma memnuniyetini artıracağ1 görülmüştür. Ayrıca, turistik tüketicilere göre online seyahat acentelerinin web siteleri kalitesinin, online seyahat acenteleri aracilığıla seyahat satın alma memnuniyetini pozitif yönde etkileyeceği saptanmıştır.

\section{TARTIŞMA, SONUÇ VE ÖNERILLER}

Yapılan araştırmadan elde edilen bulgular doğrultusunda, günümüzde iş, tatil vb. çeşitli amaçlarla seyahat satın almada, klasik seyahat acentelerinin yerini büyük oranda online seyahat acentelerinin aldığı görülmüştür. Katılımcıların yaklaşık \%50'si bir sonraki seyahat satın alma ihtiyaçlarında online seyahat acentelerini tercih edeceklerini belirtmiştir. Ayrıca, katılımcıların yaklaşık \%80'inin online seyahat acenteleri aracılığıyla seyahat satın alma deneyimlerini pozitif olarak değerlendirdikleri ve online seyahat acenteleri aracılığıyla seyahat satın almayı başkalarına önerdikleri görülmüştür.

Araştırma kapsamında, İstanbul ilini ziyaret eden yerli ve yabancı turistlerin yaklaşık \%75'inin, İstanbul ilinde ortalama altı gün kaldıkları görülmüştür. Ziyaretçilerin yaklaşık \%50'sinin İstanbul iline tatil, eğlence ve boş zamanlarını değerlendirmek amacıyla geldikleri görülürken; yaklaşık \%20'sinin iş amacıyla, $\% 11$ 'inin aile, akraba, arkadaş ziyareti amaciyla ve \%7'sinin ise sağlık, öğrenim, transit 
geçiş vb. çeşitli amaçlarla İstanbul ilini ziyaret ettikleri görülmüştür. Bu durum, İstanbul ilinin çeşitli amaçlarla ziyaret edildiğini gösteren araştırmalarla paralellik göstermektedir (Kerimoğlu ve Çıracı, 2006; İçellioğlu, 2014). Araştırmada dikkat çeken bir diğer sonuç ise, İstanbul ilini ziyaret eden turistlerin yaklaşık \%25'inin İstanbul'u alışveriş amacıyla ziyaret etmeleri olmuştur. Bu sonuçlar, alışveriş turizminde dünyada başı çeken New York, Londra, Barselona, Paris, Milano ve Venedik'in yanı sıra İstanbul'un da bir alışveriş destinasyonu olduğunu iddia eden turizm araştırmacılarının ve pazarlamacılarının görüşleri ile örtüşmektedir (Özer ve Tüzünkan, 2012; Eşerler, 2015).

Araştırma örneklemi kapsamında anketin uygulanacağı yerli ve yabancı turist gruplarından en çok Almanya uyruklu $(\% 13,6)$ turiste rastlanmıştır. İkinci sırada ise İran uyruklu $(\% 12,3)$ turiste rastlanırken; üçüncü sırada Amerika uyruklu turiste rastlanılmıştır $(\% 11,7)$. Dördüncü sırada İngiltere uyruklu $(\% 11,3)$ turiste rastlanırken, beşinci sırada Irak uyruklu $(\% 10,9)$; altıncı sırada ise Rusya uyruklu $(\% 10,6)$ turiste rastlanmıştır. Yedinci sırada Fransa uyruklu $(\% 10,4)$ turiste rastlanırken; sekizinci sırada Türkiye uyruklu $(\% 9,6)$ ve diğer ülke uyruklarına mensup $(\% 9,6)$ turistlere rastlanmıştır. 2015 Temmuz-Aralık ayları arasında yapılan bu anket uygulamasında karşılaşılan turist uyruklarının sıralamasının, 2014 ve 2015 yılları arasında İstanbul ilini ziyaret eden turistlerin ülke sıralamalarına göre çok farklı olmadığ görülmektedir (İstanbul Kültür ve Turizm İl Müdürlüğü, 2015). Ancak 2013 yılı ve öncesinde bu sıralamada Arap turistlerin yedinci sırada yer aldığı görülürken, 2014 yılı itibariyle Arap turistlerin ikinci sıraya kadar yükseldikleri görülmüştür. Dolayısıyla İstanbul ilini ziyaret eden turist uyruklarında son iki yılda Arap turistlerin oranında büyük bir artış olduğu görülmektedir. Arap turistlerdeki bu artışın sebebi, son yıllarda İstanbul ilinin alışveriş ve sağlık turizminde ön plana çıkan bir destinasyon olmasından kaynaklanmaktadır. Bu sonuçlar, Arap turistler tarafından her iki turizm türünün de bir destinasyonu ziyaret etmede önem arz ettiğini göstermektedir. Ayrıca, anket toplama sırasında Rus turistlere ulaşımın zor olduğu dikkat çekmiştir. Bu sonuç, rakamsal olarak da turizm verilerine yansımıştır. 2014 yılı ve öncesinde İstanbul ilini ziyaret eden Rus turist oranının \%5,5 olmasına rağmen, 2015 Ocak-Aralık ayları arasında bu oran \%3,9’a gerilemiştir (İstanbul Kültür ve Turizm İl Müdürlüğü, 2015). Bu durumun sebeplerinden birinin 24 Kasım 2015 tarihinde Türkiye ve Rusya arasında yaşanan siyasi kriz olduğu düşünülürken bir diğerinin ise hem Türkiye'de hem de Ortadoğu ülkelerinde yaşanan terör olaylarından kaynaklandığı düşünülmektedir.

Klasik seyahat acenteleri ile ilgili olarak katılımcılardan elde edilen sonuçlar incelendiğinde ise, katılımcıların \%54,5'inin klasik seyahat acenteleri aracılı̆̆ıla seyahat satın alma deneyimlerini pozitif olarak değerlendirdikleri görülmüştür. Ayrıca, katılımcıların \%56'sının klasik seyahat acenteleri aracılı̆̆ıla seyahat satın almayı başkalarına önerdikleri ancak sadece \%20'sinin bir sonraki seyahat satın alma ihtiyacında klasik seyahat acentelerini tercih edecekleri görülmüştür. Bu duruma sebep olarak ise katılımcıların online seyahat acenteleri aracılığıyla seyahat satın alma sırasında gerçekleştirdikleri online işlemlere kıyasla, klasik seyahat acenteleri aracılığıyla seyahat satın almayı, kişisel mahremiyetlerinin ve gizliliklerinin korunması 
açısından daha güvenilir bulmalarından kaynaklandığı düşünülmektedir. Araştırma neticesinde ortaya çıkan bu sonuçlar, Christoi ve Panagiotis (2002) ve Bennett ve Lai (2005)'in çalışmalarının sonuçları ile paralellik göstermektedir. Christoi ve Panagiotis (2002) ve Bennett ve Lai (2005) çalışmalarında, internetten satın almadaki en büyük problemlerden ilkinin satın alınan/alınacak hizmetten, web sayfasında sunulduğu şekliyle yararlanıp yararlanamama iken, diğerinin ise ödeme aşamasında veri güvenliği noktalarında ortaya çıktığını belirtmişlerdir. Ayrıca Soh vd. (1997), yapmış oldukları çalışmalarında, tüketicilerde özellikle web sitesinin güvenilirliği ve kredi kartı kullanımı ile ilgili yüksek bir kaygı düzeyinin olduğuna dikkat çekmiştir. Dolayısıyla bu çalışmanın sonuçları ile benzer bir şekilde literatürde de web sayfalarının güvenirliği ve kalitesi konuları üzerinde durulduğu görülmüştür.

Katılımcıların e-memnuniyet düzeylerinin \%70'in altında kaldığ1 iki faktör tespit edilmiştir. Bu faktörlerden ilk sırada, \%66,4'lük memnuniyet düzeyiyle online işlemlerin kişisel mahremiyet ve gizliliği yer alırken, ikinci sırada ise \%64,9'luk memnuniyet düzeyiyle online işlemlerin güvenilirliğinin yer aldığı görülmüştür. Bu iki faktörün diğer faktörlere oranla düşük çıkması, online seyahat acenteleri aracıllı̆ıyla seyahat satın alma işleminde katılımcıların düşük bir oranla da olsa online işlemlerin güvenilirliği, kişisel mahremiyet ve gizlilik vb. konularda tereddüt yaşadıklarını göstermektedir. Bu sonuçlar, Law ve Leung (2000), Rao (2000) ve Çetinsöz (2015)'in çalışmalarının sonuçları ile benzerlik göstermektedir. Law ve Leung (2000), internetten satın almada gönülsüz davranan kullanıcıların bu davranışlarının güvenlik probleminden kaynaklandığını belirtirken; Rao (2000) ise araştırmasında internetten satın almayı düşünen kullanıcılar için güvenliğin önemli bir konu olduğunu, dolayısıyla pazarlama müdürlerinin gerekli güvenlik tedbirlerini sağlamaları gerektiğini vurgulamıştır. Çetinsöz (2015) ise, yerli turistler üzerine yaptığı çalışmasında, tüketicilerin e-satın almada algıladıkları risk artıkça e-satın almaya karşı güvenlerinin de azalacağını belirtmiştir. Çalışmanın sonuçlarına ve ilgili literatüre bakıldığında, algılanan riskte meydana gelebilecek herhangi bir artışın, online satın almada güven faktörünü olumsuz etkilediği görülmüştür.

Online seyahat acentelerinin web sitelerinin hizmet kalitesi kriterleri ile ilgili katılımcılardan elde edilen sonuçlar, daha önce yapılan benzer çalışmaların sonuçlariyla desteklenmektedir (George ve Stefanos, 1999; Jeong vd., 2001; Gefen vd., 2003; Pırnar, 2005). Jeong vd. (2001)'in yapmış oldukları araştırmada, yüksek kaliteli hizmetle desteklenmiş internet sitesi bilgilerinin müşteri tatmini açısından olumlu bir etkiye sahip olduğu vurgulanmıştır. Ayrıca bu etkinin, müşterilerin ürün değerini algılamasına da katkı sağlayabileceği belirtilmiştir. George ve Stefanos (1999) ise, internet sitesinin markasının kabul edilebilirliği ve çekiciliğinin dikkate alınmasının esatın almada önemli olduğunu ifade etmiş ve bu etkenlerin de müşterilerin belirli internet sitelerinden satın alma kararlarını etkilediğini belirtmiştir. Pırnar (2005) ise, eturizm ile ilgili yapmış olduğu çalışmasında; web sitesinin sürekli güncelleştirilmesinin gerektiğini, kullanım kolaylılığı sağlamasını, müşterilerin izlenmesini, kullanılan dil ve tasarımın uygunluğunu ve web sitelerinin geliştirilmeye elverişli şekilde düzenlenmesi gerektiğini ifade etmiştir. Gefen vd. (2003), online alışveriş yapmış deneyimli 
tüketicilerin üzerinde yaptıkları araştırmalarında, tüketicilerin web sitelerinde algıladıkları kullanım kolaylığı arttıkça e-satın almaya karşı da güvenlerinin arttığını belirtmiştir. Çalışmanın sonuçları ve ilgili literatür incelendiğinde, web sitenin kalitesi arttıkça, tüketicilerin online satın alma niyetlerinin satın alma davranışına dönüştüğü görülmektedir.

$\mathrm{Bu}$ çalışmanın bulguları 1şı̆̆ında, turizm ve seyahat endüstrisi pazarlamacılarına birtakım önerilerde bulunulmuştur. İlk olarak, online seyahat acentelerinin web sitesi tasarlayıcılarına, turistik tüketicilerin her kesiminin algılayabileceği kolaylıkta bir web sitesi stratejisi geliştirmeleri önerilmektedir. Ayrıca, online seyahat acentelerine web sitelerini düzenli ve sürekli olarak güncellenmeleri, bir iletişim sayfası ve çağrı merkezlerinin bulunması, web sitelerinde ödeme güvenliği ve kişisel bilgilerin gizliliğini sağlayacak bir güvenlik programı kullanmaları, web sitelerinin hızını yüksek tutmaları, web sitelerinde sunulan hizmetlerle ilgili görsel bilgilerin (video, fotoğraf) yer almasını ve web sitelerinin popülerliğini artırmaları tavsiye edilmektedir. Kullanıcıların vakit kaybetmeden istediği bilgiye/bilgilere ulaşabilmesini sağlayan, kullanıcılara sade, kullanışlı ve hızı yüksek bir web sitesi sunan, web sitesini kolay ve anlaşılır bir dille oluşturan ve web sitelerinde ziyaretçilerin aradığı bilgiye hızlıca ulaşmasını sağlayabilmek için site haritası, site içi arama motoru vb. uygulamalar bulunduran online seyahat acenteleri, rakiplerinden bir adım daha önde olacaktır.

Araştırma bulguları, online seyahat acenteleri aracılığıyla seyahat satın alma işleminde, düşük bir oranla da olsa online işlemlerin güvenilirliği ve kişisel mahremiyetin sağlanması konularında turistik tüketicilerin tereddüt yaşadıklarını göstermiştir. Turistik tüketicilerin online satın alma sırasında tüketicilerin korsan firma saldırıları ve dolandırılma gibi olumsuz bir durumla karşı karşıya kalma endişelerinin bulunmaması önem arz etmektedir. Bu nedenle online seyahat acentelerinin SSL sistemi gibi online ödeme güvenlik sertifikaları ile turistik tüketicilerin kişisel verilerini mahremiyet ve gizlilik prensiplerine uygun bir şekilde koruması, gizli tutması, bireysel hakları gibi konularda güvenliği sağlamaları ve turistik tüketicileri bu durumun sağlandığına ikna etmeleri gerekmektedir. Böylece ziyaretçiler, online seyahat acentelerinin web sitelerinde daha fazla vakit geçirecek ve bu süreçte rezervasyon veya satın alma işlemi yapmak için ikna olacaklardır.

Online işlemlerin güvenilirliğinin sağlanması adına acentelerin alacağı güvenlik tedbirlerinin yanında, ülkelerin ceza yasalarının da online satın almada aldatılma, dolandırılma gibi tüketicinin mağdur edilme olasılığına karşın caydırıcı ve ölçülü olması gerekmektedir. Örneğin, 5237 Sayılı Yeni Türk Ceza Kanununda basit dolandırıcılığın cezası 1-5 yıl arası hapis +5000 güne kadar adli para cezasıdır. Bahsi geçen adli para cezası en az 20, en fazla 100 Türk Lirası'dır. Nitelikli dolandırıcılığın cezası ise 2-7 yıl arası hapis +5000 güne kadar adli para cezasıdır (Canbolat, 2010). Satıcıların online dolandırıcılık yapmalarına karşı mevcut ceza kanununun yeterli olmadığı görülmekle birlikte, sık sık çıkarılan aflar da cezanın caydırıcılığını önlemektedir. Ceza kanununda yer alan bu ve benzeri durumlar, internet dolandırıcılığını teşvik etmektedir. Bu noktada online satın almada karşılaşılan 
dolandırıcılık suçlarıyla ilgili cezai yaptırımların daha caydırıcı ve teknolojik gelişmelerle birlikte güncellenmesi elzemdir.

$\mathrm{Bu}$ çalışmada turistik tüketicilerin, klasik seyahat acentelerine kıyasla online seyahat acentelerini daha çok tercih ettikleri sonucuna varılmıştır. Günümüz yoğun yaşam koşullarında, online seyahat acentelerinin tüketicilere gerek zaman tasarrufu sağlaması gerekse 7/24 doğrudan ve anında bilgi erişimi sunması, seyahat satın almada online seyahat acentelerinin daha başarılı ve tercih edilir bir araç olarak algılanmasına sebep olmaktadır. Ancak, online seyahat acenteleri aracilığıyla satın almada online işlemlerin güvenliği ve kişisel mahremiyetin sağlandığı düşüncesi kuşku ile karşılanmaktadır. Günümüzde online satın almanın en zayıf tarafı ise güvenlik sorunudur. Literatürde de var olduğu gibi, özellikle gelişmemiş ve gelişmekte olan ülkelerde internetin hem bilgi dağıtımında, hem de elektronik ticaret alanında önemli güvenlik eksikleri bulunmaktadır. Bu bilgiler, turistik tüketicilerin düşünceleriyle de örtüşmektedir. Online seyahat acentelerinin, giderek artan rekabeti gelecekte daha iyi karşılayabilmeleri ve ayakta kalabilmeleri açısından internetin üstün yanlarından daha çok yararlanmaları gerekmektedir. Online seyahat acentelerinin, en büyük zayıflığ olarak görünen güvenlik sorununu en aza indirgemek için gelişmiş güvenlik programları gibi önlemler alabilmeleri mümkündür. Ayrıca, online seyahat acentelerinin web siteleri hizmet kalitesinin, online seyahat acenteleri aracılığıyla seyahat satın alma memnuniyetini pozitif yönde etkilediği görülmüştür. Bu nedenle internet üzerinden pazarlamada başarılı olmak isteyen acentelerin, online pazarlama stratejilerini etkin bir biçimde uygulamaları ve web sitelerinin hizmet kalitesine önem vermeleri gerekmektedir.

\section{KAYNAKÇA}

Altunışık, R., Coşkun R., Bayraktaroğlu, S., Yıldırım, E. (2010). Sosyal Bilimlerde Araştırma Yöntemleri: SPSS Uygulamalı, Sakarya: Sakarya Yayınclık.

Barnes, S., ve Vidgen, R. (2002). An Integrative Approach to the Assessment of E-Commerce Quality, Journal of Electronic Commerce Research, 3(3), 114-27.

Bennett, M. M., ve Lai, C. W. K. (2005). The Impact of the Internet on Travel Agencies in Taiwan, Tourism and Hospitality Research, 6(1), 8-23.

Bronner F., de Hoog, R. (2016). Travel Websites: Changing Visits, Evaluations and Posts, Annals of tourism research, 57, 94-112.

Canbolat, S. (2010). Yeni Türk Ceza Kanununda Dolandırıcllı Davaları,18 Nisan 2016 tarihinde http://selahattincanbolat.av.tr/page7.html adresinden erişildi.

Chen, C. F., ve Kao, Y. L. (2010). Relationships Between Process Quality, Outcome Quality, Satisfaction, and Behavioural Intentions for Online Travel Agencies-Evidence from Taiwan, The Service Industries Journal, 30(12), 2081-2092.

Christou, E., ve Kassianidis, P. (2002). Consumer's Perceptions and Adoption of Online Buying for Travel Products, Journal of Travel and Tourism Marketing, 12(4), 93-107.

Davies, T. ve Cahill, S. (2000), Environmental implications of the tourism industry, Resources for the Future, Washington. 
Eşerler, B. (2016). Turizmin Davos'u İstanbul'da Gerçekleşecek. 19 Nisan 2016 tarihinde http://www.turizmglobal.com/turizmin-davosu-istanbulda-gerceklesecek/ adresinden erişildi.

İçellioğlu, C. Ş. (2014). Kent Turizmi ve Marka Kentler: Turizm Potansiyeli Açısından İstanbul'un Swot Analizi, Sosyal Bilimler Dergisi, 1, 37-55.

Games, P. A. (1971). Multiple Comparisons of Means, American Educational Research Journal, 531565.

Gefen, D., Karahanna, E., ve Straub, D. W. (2003). Trust and TAM in online shopping: an integrated model. MIS quarterly, 27(1), 51-90.

Gretzel, U., Yoo, K. H. (2008). Use and Impact of Online Travel Reviews, Information and communication technologies in tourism, 35-46.

Karataş, M., ve Babür, S. (2013). Gelişen Dünya'da Turizm Sektörünün Yeri. KMÜ Sosyal ve Ekonomik Araştırmalar Dergisi, 15(25), 15-24.

Kaynama, S. A., ve Black, C. I. (2000). A Proposal to Assess the Service Quality of Online Travel Agencies: An Exploratory Study, Journal of Professional Services Marketing, 21(1), 63-89.

Kerimoğlu, E., ve Çıracı, H. (2010). İstanbul'da Uluslararası Ziyaretçilerin Memnuniyet Düzeyleri, İTÜDERGÍSİ/a, 5(1).

Kim, D. J., Kim, W. G., ve Han, J. S. (2007). A Perceptual Mapping of Online Travel Agencies and Preference Attributes, Tourism management, 28(2), 591-603.

Millan, A., ve Esteban, A. (2004). Development of a Multiple-Item Scale for Measuring Customer Satisfaction in Travel Agencies Services. Tourism Management, 25(5), 533-546.

Nakip, M. (2004). Pazarlama Araştırmalarına Giriş (SPSS Destekli), Ankara: Seçkin Yayıncılık.

Özer, S. U., ve Tüzünkan, D. (2012). Alışveriş Turizmi Kapsamında 'İstanbul Shopping Fest' ve Yansımaları, 13.Ulusal Turizm Kongresi Akdeniz Üniversitesi Antalya, 151-166.

Pırnar, İ. (2005). Turizm Endüstrisinde E-Ticaret, Ekonomik ve Sosyal Araştırmalar Dergisi, 1, 2855.

Rianthong, N., Dumrongsiri, A., ve Kohda, Y. (2016). Improving the Multidimensional Sequencing of Hotel Rooms on an Online Travel Agency Web Site, Electronic Commerce Research and Applications, 17, 74-86.

Sanchez-Franco, M. J., ve Rondan-Cataluna, F. J. (2010). Virtual Travel Communities and Customer Loyalty: Customer Purchase Involvement and Web Site Design, Electronic commerce research and applications, 9(2), 171-182.

Szymanski, D. M., ve Hise, R. T. (2000). E-satisfaction: an initial examination. Journal of retailing, 76(3), 309-322.

Ulrich, D. (2013). Human Resource Champions: The Next Agenda for Adding Value and Delivering Results, Harvard: Business Press. 
Ünal, A., ve Demirel, G. (2011). Sağlık Turizmi İşletmelerinden Yararlanan Müşterilerin Beklentilerinin Belirlenmesine Yönelik Bolu İlinde Bir Araştırma, Electronic Journal of Vocational Colleges, 1(1).

Webster, J. (2014).Shaping Women's Work: Gender, Employment and Information Technology, Routledge. 